\title{
DE LA INEXISTENCIA DEL MATRIMONIO EN EL DERECHO CHILENO
}

\author{
Javier Barrientos Grandón*
}

\begin{abstract}
RESUMEN
Se examina la disciplina de los requisitos de existencia del matrimonio en el nuevo Derecho Matrimonial chileno, a la luz de la ley 19.947, doctrina y jurisprudencia. Se analizan también sus relaciones con los requisitos de validez y el régimen jurídico de la declaración de inexistencia en el evento de la ausencia de los requisitos de: diversidad de sexo de los contrayentes, consentimiento, presencia del Oficial del Registro Civil e inscripción del matrimonio religioso.
\end{abstract}

\section{MATRIMONIO - REQUISITOS DE EXISTENCIA - INEXISTENCIA}

\section{The legal recognition of marriage under Chilean law}

\begin{abstract}
This is a look at the requirements for the legal recognition of marriage under the new Chilean Marriage Act. The study also analysis their relations to validity requirements and the legal regime for the declaration of inexistence in cases as equal sex of the contracting parties, absence of consent, absence of the public officer and not registration of the religious marriage.
\end{abstract}

MARRIAGE - REQUIREMENT FOR LEGAL RECOGNITION - LEGAL RECOGNITION

* Abogado. Doctor en Derecho. Profesor de Historia del Derecho, Universidad Diego Portales, Investigador Fundación Fernando Fueyo Laneri. Academia Chilena de la Historia. República 105; Santiago de Chile. Correo electrónico: javier.barrientos@udp.cl. Artículo recibido el 22 de septiembre de 2006 y aceptado para su publicación por el Comité Editorial el 6 de noviembre de 2006. 


\section{CONSIDERACIONES PRELIMINARES}

$\mathrm{L}$ a nueva "Ley de Matrimonio Civil" ha innovado ampliamente en sede de "requisitos" del matrimonio, y lo ha hecho no sólo en su terminología, sino también en su contenido, sobre el cual ya comienza a aparecer una interesante y activa elaboración de la doctrina que intenta algunas sistematizaciones de carácter general, ${ }^{1}$ cuanto sobre cuestiones en particular, de las que se dará noticia a lo largo de estas páginas.

A diferencia de la "Ley de Matrimonio Civil" de 1884, la de 2004, asume expresamente la denominación: "requisitos para contraer matrimonio", con la paladina declaración según la cual ella, entre otros objetos, está destinada a regularlos. ${ }^{2}$ En efecto, el inciso $2^{\circ}$ de su artículo 1 se inicia con el siguiente paso: "La presente ley regula los requisitos para contraer matrimonio...”, y, con una precisión, vuelve a utilizar esta denominación en la rúbrica del párrafo $1^{\circ}$ de su capítulo II: “De los requisitos de validez del matrimonio”, y en el inciso $1^{\circ}$ del artículo 20 vuelve a referirse a "los requisitos contemplados en la ley", si bien en su inciso segundo recurre a la expresión: "exigencias que la ley establece para su validez", aunque en el inciso siguiente vuelve a la frase "requisitos legales", y en el que sigue a la de: "requisitos exigidos por la ley". Por su parte, en su artículo 80 recurre a la frase: "Los requisitos de forma y fondo del matrimonio", y en el nuevo artículo 40 bis número 10 introducido en la ley de Registro Civil se recibe la fórmula: "exigencias establecidas en la ley para la validez del matrimonio civil".

Tales "requisitos" han sido calificados por la ley como de "validez" (rúbrica párrafo $1^{\circ}$ Cap. III, y art. 20 inc. $2^{\circ}$ ), al igual que en uno de los nuevos artículos de la "Ley de Registro Civil” (art. 40 bis número 10), de manera que, en principio, pareciera que ella no regula los "requisitos de existencia" del matrimonio.

Pero, sin perjuicio de lo anterior, la "Ley de Matrimonio Civil", bajo la rúbrica: "De los requisitos de validez del matrimonio", declara en su artículo 4, no cuáles sean los "requisitos de validez del matrimonio", sino las "exigencias" que debe cumplir la "celebración del matrimonio": "La celebración del matrimonio exige que ambos contrayentes sean legalmente capaces, que hayan consentido libre y espontáneamente en contraerlo y que se hayan cumplido las formalidades que establece la ley". La evidente incoherencia que se advierte entre la terminología utilizada en la rúbrica y en el cuerpo del artículo 4, pareciera que debe resolverse a favor de una interpretación de este último conforme a la cual en él se incluyen: a) requisitos de validez del matrimonio; y b) otros requisitos que no son de validez. Veamos:

${ }^{1}$ Vid. Court Murasso, E. Nueva Ley de Matrimonio Civil. Ley 19.947, Universidad Adolfo Ibáñez-Legis, Bogotá, 2004, Barrientos Grandón, J. y Novales Alquézar, A. Nuevo derecho matrimonial chileno, LexisNexis, Santiago de Chile, 2004; López Díaz, C. Manual de Derecho de Familia y Tribunales de Familia, Librotecnia, Santiago de Chile, 2005; García Cantero, G., "Chile estrena divorcio (Ley 17 de mayo 2004", en Actualidad Civil, 5, Madrid, 2005, pp. 517-533.

${ }^{2}$ La ley de 1884 sólo utilizaba en dos casos la palabra "requisitos", y lo hacía para referirse a los exigidos por "la religión a que pertenecieren" los contrayentes (art. 1 inc. $2^{\circ}$ ) y para declarar expresamente que: "no se tomarán en cuenta esos requisitos y formalidades para decidir sobre la validez del matrimonio, ni para reglar sus efectos civiles" (art. 1 inc. $3^{\circ}$ ). 
a) Capacidad legal: pareciera ser éste un claro requisito de validez, si bien, como se advertirá en su lugar, alguna interpretación puede admitir que bajo él podría contenerse algún "requisito de existencia".

b) Consentimiento libre y espontáneo: este también aparece como un claro requisito de validez del matrimonio, porque presupone la existencia del consentimiento, ya que lo exigido es la "libertad” y la "espontaneidad” de él. Así, entonces, la ley 19.947 no regula aquí la exigencia del "consentimiento", que es un "requisito de existencia" del matrimonio, cuya total ausencia implica que el matrimonio no existe.

c) Formalidades que establece la ley: algunas de las formalidades que prescribe la ley son claramente "requisitos de validez" del matrimonio, o de ciertos matrimonios, como la presencia de dos testigos, exigida directamente para los matrimonios celebrados ante el Oficial del Registro Civil (art. 17 inciso $2^{\circ} \mathrm{LMC}$ ), cuya falta acarrea la nulidad del matrimonio (art. 45 LMC). Esta formalidad no se exige directamente en la celebración de los matrimonios "ante entidades religiosas de derecho público" (art. 20 LMC), aunque debe entenderse que también les es aplicable supuestas algunas disposiciones particulares de la ley (art. 20 inc. $2^{\circ}$ ) y de la ley de Registro Civil (arts. 40 bis, 40 ter), y según se desprende de la historia fidedigna de su establecimiento. ${ }^{3}$

La citada trilogía de "requisitos", que se contiene en el artículo 4 de la "Ley de Matrimonio Civil", es reiterada en sede de nulidad del matrimonio, pues en su artículo 44 se consagran sólo dos grandes capítulos de nulidad del matrimonio, complementados por un tercero previsto en el artículo 45, a saber: a) existencia de alguna de las "incapacidades" previstas en los artículos 5, 6 y 7 de la misma ley; b) falta de "consentimiento libre y espontáneo" en los términos de su artículo 8 y, c) falta en la celebración del número de testigos hábiles previstos en su artículo 17.

En concordancia con la adopción de la categoría de "requisitos", la "Ley de Matrimonio Civil" ha tendido a prescindir de la noción jurídica de "impedimentos", sobre la cual se estructuraba el régimen de la ley anterior, cuyo título segundo, precisamente se rubricaba: "De los impedimentos y prohibiciones". ${ }^{4}$

${ }^{3}$ La Comisión de Constitución del Senado en su "Segundo Informe", al tratar de una indicación relativa a alterar el inciso $1^{\circ}$ del actual artículo 20 de la ley, hizo expresa referencia a la aplicación de la formalidad de dos testigos en los matrimonios celebrados ante entidades religiosas: "La Comisión consideró que no sólo es preciso el cumplimiento de los requisitos de capacidad y consentimiento, sino que también la presencia de los testigos hábiles, puesto que todos apuntan a la validez del matrimonio" ("Segundo Informe de la Comisión de Constitución, Legislación, Justicia y Reglamento, recaído en el proyecto de ley, en segundo trámite constitucional, que establece una nueva ley de matrimonio civil", Valparaíso, 15 de diciembre de 2003, Boletín 1.759-18, p. 36).

${ }^{4}$ No se ha dicho que haya prescindido, sino que sólo "ha tendido a prescindir", supuesto que ha recurrido a la expresión "impedimento" en algunas de sus disposiciones, a saber: a) art. 6 inciso 2, en el cual se dice que: "Los impedimentos para contraerlo (el matrimonio) derivados de la adopción se establecen por las leyes especiales"; b) artículo 14, al señalar que en el momento en que los interesados se presenten a hacer manifestación ante el Oficial del Registro Civil deberán rendir información de dos testigos por lo menos "sobre el hecho de no tener impedimentos ni prohibiciones para contraer matrimonio"; c) art. 40 bis LRC, re- 
Por lo que se lleva dicho, y supuesto que la ley impone como sanción la "nulidad del matrimonio" para la ausencia de aquellos que tiene como requisitos, parece razonable adoptar la nomenclatura de "requisitos de validez del matrimonio". El primero de tales requisitos es el de la "capacidad legal de los contrayentes" (art. 4 LMC) la que, en los artículos 5, 6 y 7 de la ley están definidos por vía negativa, es decir, por la de señalar taxativamente las "incapacidades" (art. 44 letra a), esto es, las personas que "no podrán contraer matrimonio" (art. 5 inc. 1 LMC). ${ }^{5}$ El segundo requisito es el del "consentimiento libre y espontáneo" (art. 4 LMC.), definido también por la vía negativa, es decir, mediante el señalamiento de aquellos casos en los cuales se entiende que "falta", y que son los señalados en los tres números del artículo 8 de la ley, cuya concurrencia acarrea también la nulidad del matrimonio (art. 44 letra b). El tercer y último requisito de validez del matrimonio es el cumplimiento de ciertas formalidades legales (art. 4 LMC), limitada a la celebración del matrimonio en presencia de dos testigos hábiles (art. 17), cuya ausencia también causa la nulidad del matrimonio (art. 45).

La "Ley de Matrimonio Civil" regula (art. 1 inc. $2^{\circ}$ ), entonces, "los requisitos de validez del matrimonio" (Cap. II, § 1), cuya ausencia sanciona con la correspondiente declaración de nulidad (arts. 44 y 45), pero ella, al igual que su antecesora, no "regula" la exigencia de otra serie de "requisitos", para cuya falta no está expresamente prevista la "nulidad del matrimonio" y, respecto de la cual, aparece como defendible la ausencia de matrimonio civil, es decir, la "inexistencia" del matrimonio ante la ley civil.

Así, parece también aconsejable conservar la nomenclatura tradicional de la doctrina referida a los "requisitos de existencia" del matrimonio civil, aunque alguno de ellos sea, en propiedad, un "elemento esencial" del matrimonio. Tales "requisitos de existencia" del matrimonio civil reglado por la ley 19.947 en concordancia con el Código Civil y la ley de Registro Civil, son: a) diversidad de sexo de los contrayentes; b) consentimiento; c) presencia del Oficial del Registro Civil; d) inscripción del matrimonio religioso.

En resumen, el esquema general de los requisitos exigidos, en el nuevo sistema matrimonial chileno, para que exista y valga un matrimonio civil es el siguiente: a) Requisitos De existencia del matrimonio Civil: 1. Diversidad de sexo de los contrayentes; 2. Consentimiento; 3. Presencia del Oficial del Registro Civil; 4. Inscripción del matrimonio religioso; b) REQUisitos DE VALIDEZ DEL MATRIMONIO CIVIL: 1. Capacidad

ferido a las menciones del acta expedida por la entidad religiosa ante la cual se desarrolló la primera fase del matrimonio, que indica que debe constar el testimonio de los testigos: "sobre el hecho de no tener ninguno de los contrayentes impedimento o prohibición legal para contraer matrimonio”. Nótese que en el artículo 54 inciso 2 número $5^{\circ}$, la LMC utiliza la voz 'impedimento' en un sentido diverso al aquí referido, pues señala que se incurre en la causal de divorcio cuando concurre: "Alcoholismo o drogadicción que constituya un impedimento grave para la convivencia armoniosa entre los cónyuges o entre éstos y los hijos”.

${ }^{5}$ Es desde este ángulo negativo de la capacidad para contraer matrimonio desde el que se ha conservado la noción de "impedimento" en la "Ley de Matrimonio Civil" (art. 6 inc. $2^{\circ}$ y art. 14) y en la del Registro Civil (art. 40 bis). Y, supuesto que todos ellos obstan a la validez del matrimonio y su concurrencia acarrea la nulidad del mismo (art. 44 letra a), naturalmente, tal voz 'impedimento' sólo se utiliza en su restringida y antigua canónica acepción de "impedimentos dirimentes". 
legal de los contrayentes; 2. Consentimiento libre y espontáneo de los contrayentes; 3. Cumplimiento de ciertas solemnidades.

No ha de olvidarse, en todo caso, que, además de los requisitos de existencia y de validez del matrimonio civil, la ley 19.947 reconoce, en su artículo 9 inciso $1^{\circ}$ y artículo 14 , la existencia de ciertas "prohibiciones legales" para contraer matrimonio, que ella no menciona, pero que sí se declaran en ciertas disposiciones del Código Civil. ${ }^{6}$

\section{De la inexistencia del Matrimonio Civil}

Bien sabido es que, atribuyéndose originariamente a Zachariae la distinción entre condiciones esenciales y condiciones de validez del matrimonio, ${ }^{7}$ bajo la vigencia de la "Ley de Matrimonio Civil" de 1884, nuestra doctrina civil admitió, sin mayores discrepancias, las distinción entre "requisitos" o "condiciones" de "existencia” y "requisitos" o "condiciones" de "validez" del matrimonio, ${ }^{8}$ y desde mediados del siglo pasado la jurisprudencia aceptó también la distinción entre "matrimonio inexistente" y "matrimonio nulo": Corte de Apelaciones de Santiago, 13 de diciembre de 1921, que reconoce la diferencia entre la nulidad e inexistencia del matrimonio; 9 sentencia de primera instancia de 6 de julio de 1934, confirmada por la Corte de Apelaciones de Santiago el 28 de agosto de ese mismo año que, reconociendo la diferencia entre inexistencia y nulidad,

${ }^{6}$ Tales prohibiciones aparecen claramente diferenciadas respecto de las "incapacidades" o "impedimentos”, precisamente, mediante las partículas disyuntivas 'o' y 'ni'. Así, en el artículo 9 se hace referencia a "no tener incapacidad o prohibición legal para contraer matrimonio", y en el 14 a "no tener impedimentos ni prohibiciones para contraer matrimonio". Estas "prohibiciones legales" son de aquellas cuya disciplina fija el paso final del artículo 10 del Código Civil, en cuanto la contravención a la prohibición para contraer matrimonio no hace "nulo y de ningún valor" al matrimonio, sino que la misma ley le ha designado de manera expresa "otro efecto que el de nulidad para el caso de contravención. Las referidas "prohibiciones legales" para contraer matrimonio consignadas en el Código Civil son las siguientes: a) minoridad en relación con el consentimiento que deben prestar ciertas personas; b) guardas; y c) segundas nupcias.

${ }^{7}$ Zachariae, K. S., Le droit civil français (Traducción de la $5^{\text {a }}$ ed. en alemán), Paris, Auguste Durand, 1854, t. 1, p. 166, § 108, nota 3, pp. 169-172.

${ }^{8}$ Vide Claro Solar, L., Explicaciones de Derecho Civil chileno y comparado, Santiago de Chile, 1932, I, nr. 525-530, pp. 291-294; Fueyo Laneri, F. Derecho Civil, VI, Derecho de Familia, I, Santiago de Chile, 1959 , nr. 43-48, pp. 93-96; Meza Barros, R., Manual de Derecho de Familia², I, Jurídica de Chile, Santiago de Chile, 1989, nr. 43-45, pp. 36-37; Somarriva Undurraga, M. Derecho de Familia, I, Jurídica de Chile, Santiago de Chile, 1983, nr. 14-16, pp. 28-30; Rossel Saavedra, E. Manual de Derecho de Familia ${ }^{7}$, Jurídica de Chile, Santiago de Chile, 1993, nr. 16-19, pp. 15-17; Castro Larraín, O., "Matrimonio putativo", en Revista de Derecho y Jurisprudencia, XXXVII, Santiago de Chile, 1940, I ${ }^{\mathrm{a}}$ Parte, p. 54; Ramos Pazos, R. Derecho de familia $^{4}$, I, Jurídica de Chile, Santiago de Chile, 2003, nr. 13, pp. 32-33. En contra Velasco Letelier, E. De la disolución del matrimonio, Jurídica de Chile, Santiago de Chile, 1973, pp. 59-75.

${ }^{9}$ Corte de Apelaciones de Santiago, Santiago, 13-XII-1921, cons. $7^{\circ}$, en Revista de Derecho y Jurisprudencia, XVIII, Santiago de Chile, 1921, II ${ }^{\mathrm{a}}$ Parte, Sec. II ${ }^{\mathrm{a}}$, p. 255. Transcriben este considerando: Montero Correa, E., La nulidad en el matrimonio, Santiago de Chile, 1930, p. 10; Paul Errázuriz, H., Estudio crítico de la jurisprudencia recaída sobre los artículos $1^{\circ}$ a $8^{\circ}$ de la Ley de Matrimonio Civil, Memoria de Prueba para optar al Grado de Licenciado en Ciencias Jurídicas y Sociales de la Universidad de Chile, Santiago de Chile, 1957, p. 17; y Velasco Letelier, E., (n. 8), pp. 70-71. 
declaró esta última; ${ }^{10}$ Corte Suprema en casación de 30 de julio de 1947, que también reconoce la expresada diferencia; ${ }^{11}$ y Corte Suprema en casación de 26 de septiembre de 1953, que declaró la inexistencia de un matrimonio celebrado en el extranjero ante un cónsul de la república. ${ }^{12}$

Ahora, bajo la vigencia de la ley 19.947 la doctrina nacional ha mantenido la opinión conforme a la cual se conserva la inexistencia del matrimonio como consecuencia para la falta de sus "requisitos de existencia". ${ }^{13}$

Los argumentos sobre la base de los cuales los civilistas chilenos han defendido que en el derecho matrimonial chileno se reconoce la posibilidad de la "inexistencia" del matrimonio civil son los siguientes:

$1^{\circ}$. "No hay nulidad sin texto": la ley de 1884 fijaba taxativamente los capítulos de nulidad matrimonial en sus artículos 29, 31, 32 y 33, y entre ellos no incluía la falta de diversidad de sexo de los contrayentes, la falta del consentimiento, ni la ausencia del Oficial del Registro Civil, de guisa que, como ellos eran requisitos indiscutidos del matrimonio, su sanción no podía ser la nulidad, sino simplemente se trataba de casos de inexistencia del matrimonio. ${ }^{14}$

Este argumento mantiene su valor bajo la disciplina de la nulidad que ha fijado la ley 19.947, pues de una manera muy clara, incluso más que la empleada por la ley anterior, ha consagrado el principio conforme al cual "no hay nulidad sin texto. En efecto, en su artículo 44 señala que: "El matrimonio sólo podrá ser declarado nulo por alguna de las siguientes causales”, y a los tres capítulos de nulidad que allí señala se agrega uno, taxativamente mencionado en el artículo 45: "Es nulo el matrimonio que no se celebre ante el número de testigos hábiles determinados en el artículo 17 ". ${ }^{15}$

Se mantienen así fuera de la sede de nulidad matrimonial la ausencia de la diversidad de sexo, de consentimiento y del oficial del Registro Civil, de manera que nada

${ }^{10}$ Juez Letrado Civil. Santiago, 6-VII-1934, confirmada Corte de Apelaciones de Santiago, Santiago, 28-VIII1934, en Revista de Derecho y Jurisprudencia, XXXII, Santiago de Chile, 1935, II ${ }^{\text {P Parte, Sec. I }}$, pp. 17-21.

${ }^{11}$ Corte Suprema. Cas. civ. 30-VII-1947, cons. $9^{\circ}$, en Revista de Derecho y Jurisprudencia, XLV, Santiago de Chile, 1946, II ${ }^{\text {a }}$ Parte, Sec. I ${ }^{\mathrm{a}}$, p. 111.

${ }^{12}$ Corte Suprema. Cas. civ. 26-IX-1953, en Revista de Derecho y Jurisprudencia, L, Santiago de Chile, 1954, II ${ }^{\mathrm{a}}$ Parte, Sec. I ${ }^{\mathrm{a}}$, pp. 382-392.

${ }^{13}$ Court Murasso, E. (n. 1), pp. 5-6; López Díaz, C. (n. 1), pp. 147-148; Ramos Pazos, R. Derecho de familia ${ }^{5}$, Editorial Jurídica de Chile, Santiago de Chile, 2005, I, pp. 34-35; Corral Talciani, H., "El régimen de los requisitos del matrimonio y de la nulidad en la nueva ley de matrimonio civil", en Cuadernos de Extensión Jurídica, 11, Matrimonio civil y divorcio. Análisis crítico y criterios para la aplicación de la Ley $N^{o}$ 19.947, de 2004, Universidad de Los Andes, Santiago de Chile, 2005, pp. 42-44.

${ }^{14}$ Somarriva Undurraga, M. (n. 8), I, nr. 14, p. 28; Fueyo Laneri, F. (n. 8), VI-I, nr. 44, p. 93; Rossel Saavedra, E. (n. 8), nr. 16, p. 15 .

${ }^{15}$ En el mismo sentido Corral Talciani, H., "El régimen de Nulidad Matrimonial en la Nueva Ley de Matrimonio civil”, en Colegio de Abogados de Chile, Seminario: Nueva Ley de Matrimonio Civil, Ley $N^{\circ}$ 19.947, Santiago de Chile, 2004, p. 32; Corral Talciani, H., (n. 13), pp. 53-54. 
obsta a que se siga predicando de ellos que constituyen requisitos de existencia del matrimonio. ${ }^{16}$

2. La "no producción de efectos civiles": en tanto que el artículo 1 de la ley de 1884 disponía que: "El matrimonio que no se celebre con arreglo a las disposiciones de esta ley no produce efectos civiles", se argüía que tal carencia de efectos civiles era, precisamente, la consecuencia de no existir matrimonio, uno de cuyos casos era el del matrimonio religioso, pues respecto de él la misma disposición agregaba que los requisitos o formalidades prescritos por la religión a la que pertenecieran los contrayentes "no se tomarán en cuenta para decidir sobre la validez del matrimonio ni para reglar sus efectos civiles". ${ }^{17}$

Si bien la nueva "Ley de Matrimonio Civil" no contiene una disposición semejante a la del artículo 1 de su antecesora, el mismo argumento continúa aplicándosele, sobre la base de lo dispuesto en su artículo 20. En efecto, ha admitido también la ley 19.947 el criterio de la inexistencia del matrimonio civil a propósito del tratamiento que en su artículo 20 ha dado a la celebración de matrimonio ante entidades religiosas de derecho público. Lo ha hecho cuando en su inciso segundo dispone que si "no se inscribiere en el plazo fijado, tal matrimonio no producirá efecto civil alguno", que es la expresión utilizada por el artículo 1444 del Código Civil cuando se refiere a aquellas cosas que son de la "esencia" de un contrato y sin las cuales "o no produce efecto alguno, o degenera en otro contrato”. Así, pues, ante la falta de la citada inscripción no existe el matrimonio para la ley civil. ${ }^{18}$

$3^{\circ}$. La disciplina del matrimonio putativo: sobre la base del hoy derogado artículo 122 del Código Civil, varios autores sostenían que en él se contenía implícitamente la distinción entre "matrimonio inexistente" y "matrimonio nulo". Tal opinión se fundaba en que el referido artículo 122 señalaba que era "el matrimonio nulo" que hubiera sido "celebrado con las solemnidades que la ley requiere" el que producía "los mismos efectos civiles que el válido respecto del cónyuge que de buena fe y con justa causa de error lo contrajo; pero dejará de producir efectos civiles desde que falte la buena fe por parte de ambos cónyuges”. Así, entonces, el matrimonio inexistente no podía llegar a considerarse putativo. ${ }^{19}$

Este argumento se mantiene con la ley 19.947, pues, aunque derogó el artículo 122 del Código Civil, regló el matrimonio putativo en su artículo 51, cuyo inciso $1^{\circ}$ conserva casi inalterada la redacción del texto de Bello: "El matrimonio nulo que ha sido celebrado o ratificado ante el Oficial del Registro Civil produce los mismos efectos civiles que el válido respecto del cónyuge que, de buena fe y con justa causa de error,

\footnotetext{
${ }^{16}$ En igual sentido, el ya citado Corral Talciani, H. (n. 15), p. 32.

${ }^{17}$ Claro Solar, L., (n. 8), I, nr. 526, p. 292.

${ }^{18}$ En el mismo sentido Corral Talciani, H., (n. 15), p. 52.

${ }^{19}$ Claro Solar, L., (n. 8), I, nr. 526, p. 291.
} 
lo contrajo, pero dejará de producir efectos civiles desde que falte la buena fe por parte de ambos cónyuges". 20

Pero, además de los argumentos señalados, la ley 19.947 ofrece otros dos para defender la diferencia entre "matrimonio inexistente" y "matrimonio nulo", a saber:

$4^{\circ}$. La ley 19.947 sólo regula expresamente los "requisitos de validez" del matrimonio: este argumento, en cierto modo, es una extensión del principio conforme al cual "no hay nulidad sin texto". En efecto, la "Ley de Matrimonio Civil", de acuerdo con lo que se consigna en la parte inicial del inciso $2^{\circ}$ de su artículo 1 "regula los requisitos para contraer matrimonio", es decir, no se ocupa de los requisitos para que exista matrimonio, pues ellos están tratados básicamente en el Código Civil y, en cuanto tales, constituyen sus "requisitos de existencia".

Entonces, lo que la ley 19.947 en el inciso $2^{\circ}$ de su artículo 1 denomina "requisitos para contraer matrimonio" constituyen ciertos elementos ligados a la válida celebración del mismo y, por ello, su disciplina la fija en su capítulo II, bajo el preciso título "De la celebración del matrimonio" y, en concreto, en su párrafo $1^{\circ}$, cuya rúbrica exacta es "De los requisitos de validez del matrimonio", de guisa que ante el eventual incumplimiento de tales "requisitos de validez" el matrimonio adviene anulable.

Por lo anterior, la disciplina de los "requisitos de existencia" del matrimonio debe estructurarse sobre la base de las demás disposiciones del derecho matrimonial chileno, sin necesidad de recurrir a las reglas del derecho común de carácter patrimonial en virtud de lo que ordena el artículo 4 del Código Civil.

$5^{\circ}$. Reconocimiento del ius conubii en su dimensión negativa: el reconocimiento del ius conubii en el inciso $1^{\circ}$ del artículo 2 de la ley 19.947 en cuanto una cierta "facultad" ha de entenderse como una "libertad" fundamental de la persona humana, porque si bien es posible concebirla como capaz de ejercitarse erga omnes no lo es en relación con una persona determinada y, por ende, frente a esta facultad no existe un cierto y determinado "deber" de contraer matrimonio y, a la luz de la disciplina constitucional de la persona humana y el reconocimiento a desarrollarla en búsqueda de su mayor realización espiritual y material posible, esa libertad de contraer matrimonio debe necesariamente entenderse como comprensiva de una libertad que opera en la dimensión de la libertad de "elección" y de la libertad en cuanto "ausencia de coacción". ${ }^{21}$

El ius conubii significa en una "dimensión negativa", que toda persona tiene el derecho a ser considerada como soltera si no ha ejercitado la facultad para contraer matrimonio, es decir, si no ha dado su consentimiento, pues tal manifestación de voluntad no puede

${ }^{20}$ Así también Corral Talciani, H. (n. 13), p. 55.

${ }^{21}$ Para esto vid. Barrientos Grandón, J. "Ley 19.947 sobre matrimonio civil publicada en el Diario Oficial de 17 de mayo de 2004", en Revista Chilena de Derecho Privado. Fernando Fueyo Laneri, 2, Santiago de Chile, 2004, pp. 233-241. 
ser suplida por potestad alguna. ${ }^{22}$ Así, pues, si no ha habido consentimiento matrimonial, no hay matrimonio, precisamente, porque en tal evento no se ha ejercitado el ius conubii, de guisa que es un derecho de la persona a quien se la tiene con el estado civil de casada el exigir que se declare la certidumbre de su estado civil de soltera, supuesta la ausencia de su consentimiento y es aquí donde estriba el fundamento último que hoy día encuentra la inexistencia del matrimonio por falta de consentimiento.

Por lo que se lleva escrito, en el nuevo derecho matrimonial chileno mantiene su sitio la "inexistencia del matrimonio" y, como consecuencia de ello, la exigencia de unos "requisitos de existencia", cuya omisión acarrea, precisamente, que dicho acto no sea un matrimonio civil.

\section{De LA INEXistenCia y DE LA NULIDAD DEL MATRIMONIO CIVIL}

La jurisprudencia chilena en la tercera década del siglo XX ya aceptaba la diferencia que mediaba entre un "matrimonio nulo" y un "matrimonio inexistente", tal como terminantemente lo declaraba la Corte de Apelaciones de Santiago en sentencia del 13 de diciembre de 1921: "Conforme a las disposiciones legales, no es lo mismo matrimonio inexistente que matrimonio nulo", ${ }^{23}$ y lo reiteraba la Corte Suprema en sentencia del 30 de julio de 1947: "Debe tenerse que el matrimonio, como todo acto jurídico, puede no ser solamente nulo, es decir, anulable, sino también inexistente". ${ }^{24}$

La doctrina y jurisprudencia chilenas sentaron como quicio de la precitada diferencia la expresión legal relativa a la "producción de efectos civiles", de manera que el matrimonio inexistente en caso alguno podía producirlos, mientras que el matrimonio nulo sí podía generar ciertos efectos civiles, supuesto que el primero se presentaba como "una simple apariencia de matrimonio". ${ }^{25}$ Era esa misma diferencia la que permitía extraer como corolario suyo el que resultaba imposible jurídicamente solicitar la nulidad de un matrimonio inexistente, pues la declaración de nulidad presuponía la existencia de un

\footnotetext{
${ }^{22}$ Incluso extensible a la facultad de "no contraer matrimonio", sobre esto vid. García Cantero, G. “¿Derecho a no casarse?”, en Actualidad Civil, 1, Madrid, 2004, pp. 13-22.

${ }^{23}$ Corte de Apelaciones de Santiago, Santiago, 13-XII-1921, cons. $7^{\circ}$, en Revista de Derecho y Jurisprudencia, XVIII, Santiago de Chile, 1921, II ${ }^{\mathrm{a}}$ Parte, Sec. II ${ }^{\mathrm{a}}$, p. 255

${ }^{24}$ Corte Suprema, Cas. civ. 30-VII-1947, cons. $9^{\circ}$, en Revista de Derecho y Jurisprudencia, XLV, Santiago de Chile, 1946, II ${ }^{\mathrm{a}}$ Parte, Sec. I ${ }^{\mathrm{a}}$, p. 111.

25 Claro Solar, L. (n. 8), I, nr. 525, p. 291. La Corte de Apelaciones de Santiago en la ya citada sentencia del 13 de diciembre de 1921, asumía casi literalmente la opinión de Claro Solar, y declaraba que: "El matrimonio puede ser nulo y producir efectos civiles porque existe ante la ley, porque puede llevar en sí un vicio que puede dar lugar a la declaración de nulidad y, como consecuencia, a su disolución, en cambio un matrimonio que no ha tenido existencia legal no puede producir efectos civiles". La Corte Suprema, en sentencia de casación del 30 de julio de 1947 explicaba que la diferencia en los siguientes términos: "Mientras el primero (matrimonio nulo) tiene una existencia imperfecta por cuanto adolece de vicios en su constitución que pueden traer consigo la nulidad, el segundo no es más que una simple apariencia de matrimonio, porque carece de los elementos sin los cuales no puede concebirse el acto" (Corte de Apelaciones de Santiago, Santiago, 13-XII-1921, cons. $7^{\circ}$, en Revista de Derecho y Jurisprudencia, XVIII, Santiago de Chile, 1921, II ${ }^{\text {a }}$ Parte, Sec. II ${ }^{a}$, p. 255).
} 
matrimonio afectado por un vicio, por lo cual sí resultaba necesaria la declaración de nulidad para que un matrimonio existente y afectado por un vicio dejara de producir efectos civiles. $^{26}$

Establecida, de este modo, la distinción entre un "matrimonio inexistente" y un "matrimonio nulo", la doctrina y jurisprudencia chilenas se ocuparon en determinar las diferencias concretas que se seguían en el derecho matrimonial chileno de la aceptación de la precitada distinción. Tales eran las siguientes.

\section{1". La declaración de matrimonio putativo sólo procede respecto de un "matrimonio nulo" y no de} uno "inexistente": tal era la opinión de la doctrina chilena sobre la base del hoy derogado artículo 122 del Código Civil, y en el mismo sentido se manifestaba la jurisprudencia, pues reconocía que únicamente el matrimonio anulable, y aún después de declarado nulo, continuaba produciendo "efectos civiles" si se trataba de un matrimonio putativo. $^{27}$

Esta misma disciplina es la que ha mantenido la ley 19.947 en sus artículos 51 y 52, que son los que reglan ahora el matrimonio putativo. En efecto, en su artículo 51, precisamente, se delimita su campo operativo únicamente al caso del "matrimonio nulo" que hubiera sido "celebrado o ratificado ante el Oficial del Registro Civil", de modo que respecto de un matrimonio inexistente ante la ley civil, como lo es, por ejemplo, el religioso no "ratificado" e "inscrito", no operan los efectos de la putatividad del matrimonio. ${ }^{28}$

$2^{a}$. La nulidad de un matrimonio debe declararse para que éste deje de producir efectos civiles, mientras que la inexistencia no requiere de declaración de fondo, sólo su constatación: naturalmente la doctrina chilena sostenía unánime, bajo la vigencia de la ley de 1884, que para que un matrimonio afectado por un vicio de nulidad dejara de producir sus efectos

${ }^{26}$ Claro Solar, L., (n. 8), I, nr. 722, p. 405. Así lo sostenía, indirectamente, la sentencia de un Juzgado Civil de Santiago del 6 de julio de 1934, confirmada por la Corte de Apelaciones de Santiago en su sentencia del 28 de agosto de 1934: "Que sería excesivo, sin embargo, sostener, como lo hace el Conservador del Registro Civil en su oficio agregado a fojas 5 , que no haya tenido existencia jurídica, lo que haría inoficioso declarar su nulidad..."; y con toda claridad la ya mencionada sentencia del año de 1921: "De ahí que es legalmente imposible obtener la declaración de nulidad de un matrimonio inexistente, y la necesidad ineludible de la declaración de nulidad para la disolución de un vínculo matrimonial que ha tenido existencia, pero que no se contrajo con todas las condiciones y requisitos exigidos por la ley" (Juez Letrado Civil Santiago, 6-VII-1934, cons. $6^{\circ}$, en Revista de Derecho y Jurisprudencia, XXXII, Santiago de Chile, 1935, II ${ }^{\mathrm{a}}$ Parte, Sec. I ${ }^{\circ}$, p. 20).

${ }^{27}$ Somarriva Undurraga, M. (n. 8), nr. 16, p. 30; Fueyo Laneri, F. (n. 8), VI-I, nr. 48, p. 96; Ramos Pazos, R. (n. 8), I, nr. 13, p. 33. Por su parte la Corte Suprema en sentencia de 1947 sostenía que: "Como, según la definición del artículo 102 del Código Civil, el matrimonio es un contrato solemne y hay en él requisitos internos y externos o solemnidades, de modo que, faltando estos últimos el matrimonio sería inexistente; pero si las solemnidades o requisitos externos han sido observados y el matrimonio adolece de vicios internos, es anulable, y aún declarado nulo, produce efectos civiles lo mismo que el válido "respecto del cónyuge que de buena fe y con justa causa de error lo contrajo" (Corte Suprema, Cas. civ. 30-VII-1947, cons. $9^{\circ}$, en Revista de Derecho y Jurisprudencia, XLV, Santiago de Chile, 1946, II ${ }^{\mathrm{a}}$ Parte, Sec. I ${ }^{\mathrm{a}}$, pp. 112-113).

${ }^{28}$ Ahora Corral Talciani, H. (n. 15), p. 53; Corral Talciani, H. (n. 13), p. 55. 
era necesario que se declarara judicialmente su nulidad, pero si se estaba ante un matrimonio inexistente bastaba con la "declaración de certeza" de la inexistencia. ${ }^{29}$

Bajo la vigencia de la ley 19.947 se mantiene la citada diferencia, de modo que en el caso de la falta de un requisito de existencia, como escribe Corral Talciani: "La inexistencia opera ipso iure, no necesita de declaración judicial, o más bien, si ésta es necesaria para precaver incertidumbres se limita a constatar que no existió matrimonio". ${ }^{30}$

Adviértase, en todo caso, que, sobre la base de la naturaleza y entidad del ius conubii reconocido en el inciso $1^{\circ}$ del artículo 2 de la ley 19.947, si se tratare de un matrimonio inexistente por no haber sido ejercitada dicha facultad, la declaración de certeza habría que impetrarla en relación con el estado civil de soltero, sin perjuicio de que en este evento, o en otros, nada impida invocar en juicio la "inexistencia" del matrimonio por las vías de procedimiento adecuadas cuando se pretendiere algún derecho derivado de un matrimonio que no existe, de guisa que se podría oponer la inexistencia por vía de excepción (art. 309 número 3 CPC).

3a. La acción de nulidad tiene titulares restringidos, no así la solicitud de declaración de inexistencia: era esta otra diferencia defendida por la doctrina chilena bajo la vigencia de la hoy derogada "Ley de Matrimonio Civil" de 1884.31

La ley 19.947 mantiene una disciplina restringida de titulares de la acción de nulidad de matrimonio (art. 46), y así en este ámbito también mantiene su interés la distinción entre requisitos de existencia y requisitos de validez del matrimonio, como lo recuerda Corral Talciani: "Tal acción puede intentarla cualquier interesado (incluso moralmente)". ${ }^{32}$

4a. La acción de nulidad está, en ciertos casos, sujeta a prescripción extintiva, mientras que ella no opera en el caso de inexistencia: bajo la disciplina que reglaba la prescripción de la acción de nulidad, basada en ciertas causas, en el artículo 35 de la ley de 1884 , se fundaba esta diferencia con la solicitud de declaración de inexistencia.

Supuesta la disciplina de la prescripción de la acción de nulidad que fija la ley 19.947 en su artículo 48, se mantiene esta diferencia en relación con la solicitud para impetrar el reconocimiento del estado de soltería fundado en la inexistencia del matrimonio. ${ }^{33}$

\section{De los requisitos de existencia del Matrimonio Civil}

Bajo el imperio de la "Ley de Matrimonio Civil" del 10 de enero de 1884, tanto la doctrina cuanto la jurisprudencia reconocían que en el derecho matrimonial chileno los

\footnotetext{
${ }^{29}$ Somarriva Undurraga, M. (n. 8), nr. 16, p. 30; Fueyo Laneri, F. (n. 8), VI-I, nr. 48, p. 96.

${ }^{30}$ Corral Talciani, H. (n. 15), p. 53.

${ }^{31}$ Fueyo Laneri, F. (n. 8), VI-I, nr. 48, p. 96.

32 Corral Talciani, H. (n. 15), p. 53.

33 En el mismo sentido Corral Talciani, H. (n. 14), p. 53.
} 
requisitos de existencia del matrimonio civil eran los siguientes: a) diversidad de sexo de los contrayentes; b) consentimiento; y c) presencia del Oficial del Registro Civil. ${ }^{34}$

Como la ley 19.947 no ha innovado en las tres cuestiones citadas, tal trilogía de requisitos de existencia del matrimonio civil se mantiene, pero, sin perjuicio de ello, se ha incorporado un cuarto requisito de existencia en el caso de matrimonios religiosos destinados a producir efectos civiles, pues, de acuerdo con su artículo 20, se exige respecto de ellos la "inscripción" del matrimonio, sin la cual no "producirá efecto civil alguno". Así, pues, los requisitos de existencia del matrimonio civil en Chile son los siguientes:

$1^{\circ}$. Diversidad de sexo de los contrayentes.

$2^{\circ}$. Consentimiento.

$3^{\circ}$. Presencia del Oficial del Registro Civil.

$4^{\circ}$. Inscripción del matrimonio religioso.

\subsection{De la diversidad de sexo de los contrayentes}

En el paso inicial del artículo 102 del Código Civil se reconoce legalmente la "unidad" de la naturaleza del matrimonio, bajo la expresión "un hombre y una mujer". Tal unidad, en lo que aquí interesa, se manifiesta en que la unión ha de ser heterosexual. Este carácter esencial de la diversidad de sexo de los contrayentes, predeterminado por sus fines, ha sido reconocido también por la nueva ley 19.947 en cuanto el inciso primero de su artículo 80 desconoce los efectos de aquellas uniones no heterosexuales contraídas en país extranjero, tal cual se hizo presente en la Comisión de Constitución del Senado. ${ }^{35}$

${ }^{34}$ Claro Solar, L. (n. 8), I, nr. 527, p. 292; Somarriva Undurraga, M. (n. 8), nr. 15, p. 29; Rossel Saavedra, E. (n. 8), nr. 16, p. 15; Fueyo Laneri, F. (n. 8), VI-I, nr. 46, p. 94; Ramos Pazos, R. (n. 8), I, nr. 13, p. 32. La Corte Suprema en sentencia de casación del 6 de octubre de 1953, al declarar inexistente un "matrimonio" actuado ante un cónsul chileno en el extranjero, reconocía la referida trilogía de requisitos de existencia del matrimonio en el derecho chileno bajo el imperio de la ley de 1884: "El acto que no se celebra ante el funcionario público llamado a intervenir en él, para la ley no existe, como no existiría si los contrayentes no manifestaran ante él su voluntad de contraer matrimonio o no hubiera entre ellos diferencia de sexo" (Corte Suprema, Cas. civ. 26-IX-1953, cons. 13º , en Revista de Derecho y Jurisprudencia, L, Santiago de Chile, 1954, II ${ }^{a}$ Parte, Sec. I', p. 392).

${ }^{35} \mathrm{El}$ art. 80 inc. $1^{\circ}$ de la LMC señala que: "Los requisitos de forma y fondo del matrimonio serán los que establezca la ley del lugar de su celebración. Así, el matrimonio celebrado en país extranjero, en conformidad con las leyes del mismo país, producirá en Chile los mismos efectos que si se hubiere celebrado en territorio chileno, siempre que se trate de la unión entre un hombre y una mujer". Por su parte, la Comisión de Constitución del Senado, por la unanimidad de sus miembros rechazó, por innecesaria, la indicación para precisar que los contrayentes fueran hombre y mujer: "La indicación $\mathrm{N}^{\circ}$ 9, del Honorable Senador señor Stange, modifica el inciso primero, para incluir el requisito de que los contrayentes sean un hombre y una mujer. La Comisión estimó innecesaria esta precisión, habida consideración de que está consignada expresamente en la propia definición del matrimonio, contemplada en el artículo 102 del Código Civil, que no se altera. Adicionalmente, este proyecto, en el inciso tercero de su artículo 81 (hoy 80), exige el mismo requisito para reconocer los matrimonios celebrados en el extranjero" ("Segundo Informe...", (n. 3), p. 9). 
La diversidad de sexos de los contrayentes es, pues, condición esencial del matrimonio, y esta misma nota de esencialidad es la que precisa el campo operativo del ius conubii, de modo que ante el evento de la celebración de un pretendido "matrimonio" entre personas del mismo sexo, para la ley no existe matrimonio, pues tal acto no produce efecto alguno y, además, ha degenerado en algo diverso: un hecho de connotación afectiva que operaría, probablemente, como causa de una convivencia entre personas del mismo sexo. ${ }^{36}$

Por las diferencias que quedan anotadas entre la "inexistencia" y la "nulidad del matrimonio", si de hecho se produjera una unión entre un hombre y una mujer y durante la vida de ambos no se declarase su inexistencia, nada impediría que, muerto uno de ellos o ambos, cualquier persona que tuviere interés pueda impetrar la declaración de inexistencia, porque no queda sujeta a la regla limitadora del artículo 47 respecto del ejercicio de la acción de nulidad. La muerte no puede obrar el efecto de hacer que un acto, que no fue matrimonio durante la vida de quienes lo actuaron, comience a producir efectos civiles. ${ }^{37}$

Como ya se anticipara, y supuesto que la ley 19.947 ha eliminado la incapacidad para contraer matrimonio consistente en la impotencia perpetua e incurable, el profesor Corral Talciani ha planteado que uno de los campos operativos de tal impotencia en el nuevo derecho matrimonial chileno podría ser el de la inexistencia, es decir, que la impotencia coeundi advendría asimilada al requisito de diversidad de sexo y quedaría cubierta por él. ${ }^{38}$

\subsection{Del consentimiento}

La nueva "Ley de Matrimonio Civil" ha reconocido y destacado el papel central del consentimiento en la creación del matrimonio y con ello provee de renovado contenido a la clásica voz "contrato" con que lo califica el Código Civil, pues sin consentimiento no

\footnotetext{
${ }^{36}$ Repárese en que la única referencia que se hizo a la inexistencia del matrimonio en la discusión habida en el Senado sobre el proyecto de la nueva "Ley de Matrimonio Civil" fue realizada por el senador Parra a propósito de un eventual "matrimonio" entre personas del mismo sexo, cuya observación consta al discutirse una indicación para suprimir el actual número $2^{\circ}$ del artículo 8 de la ley 19.947, relativo al error acerca de una cualidad esencial, y en ese contexto ha de entendérsela: "Por otro lado, hay una institución jurídica que se ha olvidado en el transcurso del debate: la inexistencia. Cuando el error está referido a las cualidades esenciales y llega a su punto extremo y más grave, puede fácilmente constituir un factor de inexistencia del matrimonio, lo que también puede ser alegado en su momento. No es difícil que ese error se traduzca hoy en que alguien, creyendo que va a casarse con una mujer, se vincule a un hombre. Es una situación que, por desgracia, ha llegado a ser común en la vida actual, no al extremo de contraer el matrimonio, pero sí en las relaciones interpersonales. De modo que no puede olvidarse para ese efecto la institución de la inexistencia" (Diario de Sesiones del Senado. Nueva Ley de Matrimonio Civil, Sesión 24a Valparaíso, miércoles 7-I-2004, p. 525).

37 En el mismo sentido Claro Solar, L., (n. 8), I, nr. 528, p. 292.

${ }^{38}$ Corral Talciani, H. (n. 15), p. 53.
} 
puede haber matrimonio, ya que su entidad consiste en el real ejercicio del ius conubii (art. 2 inc. $1^{\circ}$ LMC) por parte de quienes lo contraen. ${ }^{39}$

El consentimiento de los contrayentes, en cuanto elemento constitutivo del matrimonio (consensus facit matrimonium), no puede suplirse o substituirse por ningún acto de potestad alguna, precisamente por la naturaleza del ius conubii, que contiene, necesariamente, en su dimensión de libertad "negativa", el derecho de toda persona a no ser considerada en el estado civil de casada si no ha ejercitado la facultad de contraer matrimonio mediante su propia y personal declaración de voluntad en orden a constituirlo. Si no ha existido consentimiento matrimonial es porque no se ha ejercitado el ius conubii en su dimensión positiva y, por ende, es imposible que exista matrimonio, de modo que la inexistencia del matrimonio civil por falta de consentimiento se fundamenta en el ius conubii, al igual que el consiguiente derecho a obtener la declaración de certeza sobre el estado de soltería.

Pero, sin perjuicio de la radical unidad de la existencia del consentimiento en el matrimonio basada en el ejercicio del ius conubii, el examen del consentimiento como "requisito de existencia" del matrimonio exige precisar, debidamente, que él consiste en que realmente bajo el acto celebrado o contraído haya una manifestación de voluntad y que tal voluntad sea matrimonial, es decir, este requisito cubre dos ámbitos diferentes, a saber:

$1^{\circ}$. Voluntad y su manifestación: en el matrimonio, como en todo acto o declaración de voluntad, es imprescindible que exista realmente una voluntad y que ella se manifieste.

$2^{\circ}$. Voluntad matrimonial: es preciso también que la voluntad manifestada sea de naturaleza matrimonial, es decir, que esté dirigida a la celebración del matrimonio y no a la conclusión de un acto distinto.

La ley 19.947 no se ocupa separada y expresamente de estos ámbitos del consentimiento matrimonial, porque, en términos generales, presupone la existencia del consentimiento, y por ello se limita a fijar la disciplina de los casos en los cuales falta la "libertad" y la "espontaneidad" en el consentimiento matrimonial (art. 8 LMC), es decir, los casos en los cuales, existiendo consentimiento, éste puede hallarse "viciado".

Precisada así la exigencia del consentimiento para que exista matrimonio civil, ha de decirse que la única causa de su ausencia corresponde objetivamente al no ejercicio del ius conubii por parte de los supuestos o pretendidos contrayentes. Diversos sí son los supuestos de hecho que pueden generar ese no ejercicio del ius conubii y, en consecuencia, impedir que exista matrimonio, entre otros, los siguientes: a) la ausencia de voluntad y manifestación de voluntad por fuerza física; b) la ausencia de voluntad por error en la naturaleza del consentimiento matrimonial; y c) la ausencia de voluntad por simulación. 


\subsubsection{Ausencia de consentimiento, en especial, por fuerza física}

La inmanejable variedad del mundo de los hechos puede ofrecer múltiples supuestos en los cuales el ius conubii no haya sido ejercitado por uno o ambos de los pretendidos contrayentes y, por ende, situaciones en las cuales no hubo consentimiento alguno dirigido a contraer matrimonio. ${ }^{40}$

De entre los muchos casos en los que puede no existir consentimiento uno de los de mayor interés es aquel en el cual se ejercita una fuerza física sobre una o ambas personas, de modo que sus órganos corporales externos se convierten en meros instrumentos de expresión de una voluntad ajena y no de la propia, de modo que en tales actos se advierte una carencia de libertad externa, pues el elemento que distorsiona o elimina la voluntad no tiene su origen en la propia persona, sino en un factor externo. Así, en estos casos, no se ha ejercitado el ius conubii, por lo que tampoco hay consentimiento y, por ende, no existe matrimonio. ${ }^{41}$

La "Ley de Matrimonio Civil" del año 2004 fija la disciplina de la fuerza en el número $3^{\circ}$ de su artículo 8, con expresa remisión a los artículos 1456 y 1457 del Código Civil, y su tratamiento lo sitúa en sede de "falta de consentimiento libre y espontáneo", es decir, en sede de "vicios de la voluntad". En efecto, el citado artículo 8 dispone que: "Falta el consentimiento libre y espontáneo:

“ 3 ․ Si ha habido fuerza, en los términos de los artículos 1456 y 1457 del Código Civil, ocasionada por una persona o por una circunstancia externa, que hubiere sido determinante para contraer el vínculo”.

${ }^{40}$ Podrían así mencionarse eventos que caerían en el campo del derecho penal, cuales serían, por ejemplo, aquellos en los que se lograra una inscripción de un matrimonio civil nunca celebrado, y, sobre la base del certificado de matrimonio así obtenido, se pretendiera que existió matrimonio con los consiguientes derechos y obligaciones que le son inherentes; o aquellos otros que caerían, tal vez, en el campo de la responsabilidad administrativa, como si en la inscripción de matrimonio se consignara, por el Oficial del Registro Civil, que lo contrajo una persona, cuando en realidad era otra y luego se pretendiere que la primera tiene el estado civil de casada, o el supuesto que menciona Somarriva Undurraga, M. (n. 8), nr. 15, p. 29: "Tal sería el caso, un tanto rebuscado, de que no obstante que uno de los contrayentes dijera que no desea al otro como cónyuge, el Oficial del Registro Civil los declare casados".

${ }^{41}$ Buena parte de la doctrina civil chilena se inclina por considerar que la fuerza física no constituye un "vicio del consentimiento", sino que representa un caso de "ausencia de consentimiento", cuya consecuencia es la "inexistencia" del acto y no su "nulidad”. Así Claro Solar, L., Explicaciones de Derecho Civil Chileno y Comparado, XI, De las obligaciones, II, Santiago de Chile, 1941, nr. 797, p. 192; León Hurtado, A., La voluntad y la capacidad en los actos jurídicos ${ }^{3}$, Santiago de Chile, 1990, nr. 147, p. 190; Vial del Río, V., Teoría general del acto jurídico ${ }^{5}$, Santiago de Chile, 2003, nr. 64, p. 105. En sede patrimonial, Alessandri Rodríguez y Somarriva Undurraga también consienten en que la fuerza física absoluta implica ausencia de consentimiento, mas como no admiten en el derecho patrimonial la "inexistencia" de los negocios jurídicos afirman que en tal caso igualmente dicho acto sería nulo, de nulidad absoluta, Alessandri Rodríguez, A. - Somarriva Undurraga, M., Curso de Derecho Civil... redactado y puesto al día por Antonio Vodanovic H., IV. Fuentes de las obligaciones, Santiago de Chile, 1942, nr. 174, p. 138, y en la misma línea Alessandri Besa, A., La nulidad y la rescisión en el derecho civil chileno ${ }^{2}$, II, Santiago de Chile, s/f, nr. 797, pp. 720-721. 
Hay buenas razones para estimar, como aquí se estima, que el supuesto de la fuerza física o vis absoluta no está tratado en la precitada disposición de la "Ley de Matrimonio Civil”, ni tampoco en los artículos 1456 y 1457 del Código Civil, pues en estos dos textos legales únicamente se sienta la disciplina de la "fuerza" como "vicio del consentimiento", es decir, de la vis compulsiva, y así en el concreto caso del citado artículo 8 número $3^{\circ}$ de la ley 19.947 lo que se fijan no son las reglas para aquellos casos en los que la fuerza conduce a que "falte el consentimiento", sino las de aquellos en los que ella provoca que "falte el consentimiento libre y espontáneo", es decir, dicha disposición presupone que hay consentimiento y que una cierta especie de fuerza evita su "libertad" y la "espontaneidad", esto es, una fuerza que ataca determinadas calificaciones de un consentimiento existente.

Esta opinión en lo tocante a los artículos 1456 y 1457 no es nueva, pues, con rara lucidez, ya la defendían Alessandri Rodríguez y Somarriva Undurraga: "La fuerza que el legislador reglamenta en los artículos 1456 y 1457 es la fuerza vicio del consentimiento, y para que haya vicio del consentimiento es menester que haya consentimiento, porque si no lo hay no podría hablarse de consentimiento. Luego, si es de tal naturaleza que excluye el consentimiento del sujeto, ya no cabe hablar de fuerza. La ley estima que existe fuerza cuando un individuo, pudiendo decir no, dijo sí por miedo al castigo. Si la fuerza es de tal índole que priva al sujeto de voluntad, no hay fuerza". 42 El único matiz que conviene realizar a esta opinión es que cuando existe "fuerza" que excluye la voluntad, lo que no hay es "fuerza" en la noción "legal" de los artículos 1456 y 1457 , que equivale, realmente, al metus, pero sí hay fuerza en cuanto vis absoluta.

La sola lectura de los artículos 1456 y 1457 del Código Civil deja en claro que la noción de fuerza a que hacen referencia es aquella ejercida "con el objeto de obtener el consentimiento" (art. 1457), es decir, a una coacción, y lo mismo se desprende del número $3^{\circ}$ de la ley 19.947 , pues ella trata de la fuerza "determinante para contraer el vínculo", esto es, también presupone la manifestación de voluntad, mientras que en la vis absoluta ni se "obtiene" consentimiento alguno, ni nada se "contrae".

Las razones, en las cuales descansa la opinión que aquí se defiende, coincidente en esto con la de Alessandri y Somarriva, en cuanto a que el Código Civil y la ley 19.947 solamente fijan la disciplina de la fuerza como coacción son, además de la textual apuntadas tres párrafos arribas, entre otras, las siguientes: $1^{\mathrm{a}}$ ) las fuentes utilizadas por Andrés Bello para la elaboración de los actuales artículos 1456 y 1457 del Código Civil, únicamente se referían a casos de metus, es decir, de vis coactiva, pues eran las Siete Partidas, 5.5.56; 5.11.28; y 7.33.7, como se ha explicado en otro lugar; ${ }^{43} 2^{\mathrm{a}}$ ) en el caso de la fuerza física, que excluye absolutamente la voluntad, no son aplicables las exigencias señaladas en el inciso $1^{\circ}$ del artículo 1456 CC, supuesto que no tienen un papel jurídicamente trascendente ni la "impresión fuerte”, ni el “justo temor" de verse

42 Alessandri Rodríguez, A. - Somarriva Undurraga, M., (n. 41), nr. 174, p. 138.

43 Barrientos Grandón, J. "Fuentes del título 'De los actos y declaraciones de voluntad' del Código Civil", en Cuadernos de Análisis Jurídico, 28, Estudios de Derecho Civil, Universidad Diego Portales, Santiago de Chile, julio 1983, pp. 68-70. 
expuesto a un "mal irreparable y grave"; $3^{\mathrm{a}}$ ) tampoco adviene aplicable el artículo 1457 Cc en cuanto declara que la fuerza se utilice "con el objeto de obtener el consentimiento”, pues cuando hay vis absoluta no se obtiene consentimiento alguno; $4^{\mathrm{a}}$ ) por la misma razón señalada en el número anterior, no resulta aplicable a la vis absoluta el número $3^{\circ}$ del artículo 8 de la LMC, en cuanto precisa que es necesario que la fuerza hubiera "sido determinante para contraer el vínculo".

Luego, si la disciplina de la fuerza física no está fijada en el artículo 8 número $3^{\circ}$ de la "Ley de Matrimonio Civil", ella no habilita para solicitar la declaración de nulidad del matrimonio, y sí para impetrar la constatación de la inexistencia del matrimonio por falta de consentimiento. Esto es así, porque el régimen jurídico de la vis absoluta en sede matrimonial está configurado sobre la base de los principios generales que informan el ius conubii, al tenor del inciso primero del artículo 2 de la ley 19.947. En efecto, como en tales casos no ha existido ejercicio de la facultad de contraer matrimonio, no ha habido consentimiento y, por ende, menos ha podido existir matrimonio alguno, y, en virtud de la dimensión "negativa" de esta facultad o libertad nupcial, la persona afectada por la fuerza tiene el derecho a impetrar, de quien corresponda, la declaración de su estado de soltería y la consiguiente declaración de inexistencia del pretendido matrimonio.

Por todo lo que se lleva dicho, los caracteres que asume la disciplina de la fuerza física, o vis absoluta, por lo que toca al consentimiento en el matrimonio son los siguientes:

$1^{\circ}$. Recae sobre los órganos de expresión del consentimiento: ha de tratarse, necesariamente, de violencia o fuerza que se ejerce materialmente sobre los órganos físicos del contrayente, para obtener un acto que externamente expresa o significa el asentimiento a contraer matrimonio, pero que no expresa voluntad alguna de la persona, sino que manifiesta una voluntad ajena.

$2^{\circ}$. Indiferencia de la persona que ejerce la fuerza: la violencia, físicamente ejercida sobre los órganos corporales de una persona para lograr la exterioridad de un consentimiento que no es tal, puede ser obra de la otra persona que pretende la celebración del "matrimonio" o de un tercero ajeno al pretendido matrimonio que se intenta "contraer", porque nadie puede suplantar a otro en el ejercicio legítimo del ius conubii (art. 2 inc. $1^{\circ}$ LMC). ${ }^{44}$

En los casos en los que se ejerce fuerza, por el otro contrayente o por un tercero, sobre los órganos externos de una persona para generar una exteriorización del asentimiento al matrimonio no existe consentimiento, supuesto que el forzado no ha ejercido con libertad externa el ius conubii, y, en la exterioridad del acto, sus órganos físicos han obrado como

${ }^{44}$ En este punto, quizá sea el único ámbito en que las disposiciones del Código Civil y de la ley 19.947 tocantes a la fuerza de coacción coinciden con la disciplina de la vis absoluta. En efecto, de acuerdo con lo dispuesto en el artículo 1457 del Código Civil es jurídicamente irrelevante que la fuerza física sea obra de la persona del otro contrayente o de un tercero ajeno al matrimonio, criterio reafirmado por la "Ley de Matrimonio Civil" al aclarar, de forma impropia e inexacta, que basta que ella sea "ocasionada por una persona". 
meros instrumentos de una voluntad ajena, que es distinta de su voluntad interna, de manera que falta radicalmente el consentimiento y, por ende, no existe matrimonio.

\subsubsection{Ausencia de consentimiento por error en la naturaleza del consentimiento matrimonial}

En el matrimonio, como en todo acto o declaración de voluntad, se requiere no sólo la existencia de una genérica voluntad, sino de una voluntad especificada por su objeto, es decir, es necesario que el consentimiento sea matrimonial. Es, precisamente, esta la razón por la cual en la celebración ante el Oficial del Registro Civil éste sólo se limita a "declarar casados en nombre de la ley" a los contrayentes inmediatamente después de haber éstos manifestado su consentimiento al responder afirmativamente a la pregunta consistente en: "Si consienten en recibirse el uno al otro como marido y mujer", según lo previene el artículo 18 inciso segundo de la ley 19.947.

Se trata, pues, al tenor del citado inciso $2^{\circ}$ del artículo 18 de la ley 19.947 , de un consentimiento de carácter "matrimonial”, es decir, dirigido a la formación del matrimonio y no a la conclusión de otro acto o negocio jurídico, pues específicamente está definido por esa voluntad concordante de "recibirse el uno al otro como marido y mujer" y que, en cuanto tal, implica el ejercicio del ius conubii por parte de ambos contrayentes (art. 2 inc. $1^{\circ}$ LMC.).

En el derecho patrimonial, bien sabido es, este género de error de hecho (error in negotio) está regulado como "vicio del consentimiento" en el artículo 1453 del Código Civil, pero también en sede de tradición, a propósito del "error en el título" del que trata su artículo 677, si bien las fuentes romanas utilizadas por Bello en la redacción de ambas disposiciones se referían precisamente a que en tales casos "no había" acto realizado. 45

De acuerdo con el artículo 1453 del Código Civil, la casi unánime doctrina civil chilena estima que este caso de error ("obstativo" u "obstáculo") no constituye propiamente un "vicio del consentimiento", porque, realmente, impide que aquel se forme, es decir, se trata de un caso de "ausencia de consentimiento". 46 Pero, a pesar de tal uniformidad en la calificación de este género de error, y es bien sabido, no coinciden los autores en el efecto que produce: a) inexistencia del acto o negocio: tal es la opinión de Claro Solar, Pescio Vargas y Larraín Ríos; ${ }^{47}$ b) nulidad absoluta: es este el parecer de

${ }^{45}$ Vide para el caso del artículo 1453: Barrientos Grandón, J. (n. 43), pp. 61-62; y para el caso del artículo 677: Barrientos Grandón, J. "De la "tradición” y su definición en el Código Civil chileno. A propósito del artículo 670", en Revista Chilena de Derecho Privado Fernando Fueyo Laneri, 1, Santiago de Chile, diciembre, 2003, pp. 51-54 y 101-105.

${ }^{46}$ Impide la unanimidad Ducci Claro, para quien este género de error sí constituye un "vicio del consentimiento": Ducci Claro, C., Derecho Civil, Santiago de Chile, 1988, nr. 267, p. 242.

${ }^{47}$ Claro Solar, L., (n. 41), XI, nr. 769-770, pp. 150-153; Pescio Vargas, V., Manual de Derecho Civil, II, Editorial Jurídica, Santiago de Chile, 1978, nr. 160, p. 59; Larraín Ríos, H., Lecciones de Derecho Civil, Editorial Jurídica, Santiago de Chile, 1994, p. 275. 
Alessandri Rodríguez y Somarriva Undurraga, Alessandri Besa y, con matices, la de de la Maza Rivadeneira; ${ }^{48}$ c) nulidad relativa: a juicio de Barros Errázuriz, León Hurtado y Ducci Claro. ${ }^{49}$

Las explicadas dudas y vacilaciones sobre la solución a esta cuestión en sede patrimonial no se presentan en el caso del derecho matrimonial chileno, porque la ley 19.947 sienta una disciplina peculiar para el error en sede de matrimonio y, al efecto, en su artículo 8 números $1^{\circ}$ y $2^{\circ}$ solamente se refiere al error como "vicio del consentimiento", cuyos casos son dos: el recaído en la "identidad del otro contrayente" y el que versa sobre alguna de las "cualidades personales" del otro contrayente, en los términos que precisa. ${ }^{50}$

No se ocupa, entonces, la "Ley de Matrimonio Civil" en fijar de manera expresa la disciplina aplicable al supuesto de error que impida y excluya el consentimiento matrimonial, y, ante tal situación y al igual que lo ocurrido en sede de vis absoluta, no ha de acudirse a las reglas del derecho común, sino a las propias del derecho matrimonial, que derivan de la naturaleza y caracteres del ius conubii (art. 2 inc. $1^{\circ}$ LMC).

Así, si se presentara un caso en el que uno, o ambos de los pretendidos contrayentes, incurriera en un error de hecho sobre la especie misma del acto matrimonial (error in negotio), es decir, no entendiera contraer matrimonio según sus elementos esenciales, determinados por sus fines, sino un acto diverso, simplemente no habría ejercido el ius conubii y, por ende, no se habría formado consentimiento matrimonial alguno, de modo que no existiría matrimonio y, en virtud de la dimensión negativa de la libertad nupcial, podría impetrar que se declarase su estado de soltería y la inexistencia del supuesto matrimonio.

Este caso teórico, aparece hoy casi imposible de concretarse, debido a los resguardos que la "Ley de Matrimonio Civil" ha tomado para asegurar la "seriedad", y "plenitud" del consentimiento matrimonial, por ejemplo en la manifestación (art. 9) y en los deberes que se imponen al Oficial del Registro Civil de informar y prevenir a los contrayentes acerca de las finalidades del matrimonio y de los derechos y deberes recíprocos que genera (art. 10).

Sin perjuicio de lo señalado, es posible apuntar aquí, que bajo la vigencia de la ley de 10 de enero de 1884, los tribunales de justicia conocieron de un caso en el cual claramente se estaba en presencia de ausencia de consentimiento por error en la naturaleza del consentimiento matrimonial, si bien la Corte de Apelaciones de Santiago lo resolvió por la vía del vicio del consentimiento matrimonial constituido por lo que en aquella época se conocía como "rapto de seducción”.

${ }^{48}$ Alessandri Rodríguez, A. - Somarriva Undurraga, M. (n. 41), nr. 150, p. 115; De la Maza Rivadeneira, L., Derecho Civil. Contratos, Santiago de Chile, 1954, pp. 79-80; Alessandri Besa, A. (n. 41), II, nr. 762, pp. 695-696.

${ }^{49}$ Barros Errázuriz, A., Curso de Derecho Civil. Segundo Año. Según el programa aprobado por la Facultad de Derecho de la Universidad del Estado ${ }^{3}$, Santiago de Chile, 1921, p. 206; León Hurtado, A. (n. 39), nr. 134, pp. 167-169; Ducci Claro, C., (n. 46), nr. 267, p. 242.

${ }^{50} \mathrm{Vid}$. De la Maza Gazmuri, I. "El error en las cualidades personales del otro contrayente en la Ley 19.947", en Ius et Praxis. Derecho en la Región, Año 11, No 1, Talca, 2005, pp. 11-35. 
Los hechos fueron los siguientes: una niña de quince años, de ascendencia árabe que ni hablaba ni entendía bien la lengua castellana, fue llevada por un desconocido desde el colegio en el que se encontraba en clases, con el pretexto de que concurriera a probarse un vestido, a una oficina donde la hicieron firmar unos papeles en blanco, tras lo cual fue devuelta a su colegio. Tales papeles en blanco eran el acta de matrimonio. Naturalmente, en este caso la mujer no pudo manifestar un consentimiento matrimonial, porque, según lo poco que pudo entender, debido al desconocimiento del idioma castellano, supuso que firmaba unos papeles para adquirir un vestido y no para contraer matrimonio. Caso claro de error en la naturaleza del acto matrimonial.

La Corte de Apelaciones de Santiago en su sentencia del 27 de julio de 1922 declaraba: "Que, según el acta de fs. 2, la Seidan, al tiempo de contraer matrimonio sólo tenía 16 años de edad y declarando en esta instancia a fs. 163, expresa que no ha firmado su matrimonio con Salas; que con el pretexto de ir a una tienda se la llevó a una oficina, donde una persona desconocida para ella la hizo firmar unos papeles, sin darse cuenta de lo que pasaba, porque tenía en esa fecha sólo 15 años y muy poco hablaba y entendía el castellano; que inmediatamente después de firmar regresó al Colegio y que, no habiendo hablado nunca con Constantino Salas, jamás éste la ha solicitado en matrimonio". ${ }^{1} \mathrm{La}$ Corte, como se dijera, declaró nulo el matrimonio por "rapto de seducción”.

\subsubsection{Ausencia de consentimiento por simulación}

El derecho común exige que la declaración de voluntad de quien ejecuta o celebra un acto o negocio jurídico sea real y seria, en cuyo defecto se abre la puerta a la "simulación", es decir, a un supuesto en el cual se produce una divergencia consciente entre la voluntad interna o real y la voluntad externa o declarada, que puede envolver una "simulación absoluta", que se da en aquellos casos en los que las partes que simulan el consentimiento no pretenden la realización de acto alguno, o una "simulación relativa", que se presenta cuando las partes pretenden la ejecución de cierto acto, que resulta encubierto (acto disimulado) por el acto que simulan celebrar (acto simulado). ${ }^{52}$

${ }^{51}$ Corte de Apelaciones de Santiago, Santiago, 27-VII-1922, cons. 5, en Gaceta de los ribunales, Año 1922, II ${ }^{\circ}$ Semestre, Sentencia nr. 196, p. 829.

52 Sobre la simulación en el derecho chileno, además de los Manuales en uso, vide las antiguas Memorias de Fuentes Venegas, R., De la simulación, Santiago de Chile, 1936; y de Diez Duarte, R., La simulación ante la jurisprudencia, Santiago de Chile, 1944; del mismo La simulación de contrato en el Código Civil chileno: teoría jurídica y práctica forense, Santiago de Chile, 1957; Meza Barros, R., "La simulación en los negocios jurídicos", en Estudios de Derecho Civil en Memoria del Profesor Victorio Pescio, Valparaíso, 1976, pp. 265324; Paillás Peña, E., La simulación: doctrina y jurisprudencia ${ }^{2}$, Santiago de Chile, 1984; Fueyo Laneri, F., Cumplimiento e incumplimiento de las obligaciones ${ }^{2}$, Santiago de Chile, 1991, Parte IV, cap. 7 "La simulación (o falta de sinceridad contractual"; del mismo Instituciones de derecho civil moderno, Santiago de Chile, 1990, cap. 12 "La simulación de los negocios jurídicos o la falta de sinceridad contractual”; Peñailillo Arévalo, D., "Cuestiones teórico-prácticas de la simulación”, en Revista de Derecho, Universidad de Concepción, 191, Concepción, enero-junio 1992, pp. 7-28; Parra Labarca, R., La simulación: doctrina y jurisprudencia, Santiago de Chile, 1994; Lecaros Sánchez, J. M., "La acción de simulación”, en Revista de Derecho, Universidad Católica de la Santísima Concepción, 6, Concepción, 1998, pp. 91-107; Alcalde Rodríguez, E., "La simulación y 
En general, en aquellos casos en los cuales se está en presencia de una "simulación absoluta" la doctrina chilena considera que técnicamente no hay consentimiento y, por lo mismo, no existe acto o negocio alguno, sin perjuicio de lo cual se advierte una discrepancia similar a la observada en materia de error in negotio en cuanto a los efectos de la simulación, pues para unos se trata de un acto inexistente y para otros se está en presencia de un acto nulo, de nulidad absoluta. ${ }^{53}$

La simulación en el matrimonio tiene una estructura y una naturaleza diversas de la simulación en los negocios patrimoniales, en relación con lo cual no estará demás tener en cuenta las siguientes observaciones:

$1^{a}$. "Simulación total" y "simulación parcial": la simulación puede operar en dos grandes campos: a) simulación del acto mismo del matrimonio ("simulación total”); b) simulación en cuanto reserva o exclusión de algún elemento de la naturaleza del matrimonio ("simulación parcial"), como si se excluyera el fin de la procreación o el deber de guardarse fe.

$2^{a}$. "Simulación concordada" o "simulación unilateral": las señaladas dos formas de simulación pueden presentarse, o como consecuencia de la actuación concertada de varón y mujer, o como resultado de la actuación de sólo uno de ellos.

$3^{a}$. "Simulación en fraude de la ley" o "simulación en perjuicio del otro "contrayente": dos personas, concertadamente, pueden simular la celebración de un matrimonio con la finalidad de defraudar alguna ley, $v . g r$., para obtener alguna ventaja fiscal o para generar a alguna de ellas una vía de residencia legal o de obtención de la nacionalidad; pero también sólo uno de los supuestos contrayentes puede simular su voluntad matrimonial, con la finalidad de obtener alguna ventaja o provecho de la persona con quien finge contraer matrimonio. ${ }^{54}$

Sin perjuicio de las señaladas observaciones, la simulación en el matrimonio civil es una cuestión arduamente discutida en doctrina extranjera, ${ }^{55}$ sobre todo porque hay

los terceros: consideraciones civiles y penales”, en Revsita Chilena de Derecho, 27 N ${ }^{\circ}$ 2, Santiago de Chile, abril-junio, 2000, pp. 265-290.

53 Claro Solar, L., (n. 41), XI, nr. 751, p. 122; Alessandri Rodríguez, A. - Somarriva Undurraga, M., Curso de Derecho Civil. Parte general y los sujetos de derecho. $1^{a}$ parte. Explicaciones basadas en las clases de los profesores... Redactadas, ampliadas y puestas al día por Antonio Vodanovic H. ${ }^{4}$, Santiago de Chile, 1971, nr. 655, p. 500; León Hurtado, A., (n. 41), nr. 113, pp. 139-140; Vial del Río, V. (n. 41), nr. 100, p. 144; López Santa María, J., Los contratos. Parte general ${ }^{3}$, II, Santiago de Chile, 2001, nr. 59.2, pp. 383-384.

${ }^{54}$ Vid. Barrientos Grandón, J. y Novales Alquézar, A. (n. 1), pp. 119-120.

55 En derecho canónico no se presenta esta discusión, porque está expresamente regulada la "simulación" bajo la categoría de "exclusión”. En efecto en el canon 1101.1 se declara, como principio general, que: "El consentimiento interno de la voluntad se presume que está conforme con las palabras o signos empleados al celebrar el matrimonio", y en su apartado 2 advierte: "Pero si uno de los contrayentes, o ambos, excluye con un acto positivo de la voluntad el matrimonio o un elemento esencial del matrimonio o una propiedad esencial, contrae inválidamente". Así, pues, es posible que se presente una exclusión del mismo matrimonio (simulación total), o una reserva o exclusión parcial del consentimiento (simulación parcial). Vide, por ejemplo, Carrodeguas Nieto, C., "La exclusión de la educación de la prole", en Revista Española de Derecho 
autores que niegan su procedencia, supuesto que, debido a la intervención de funcionarios públicos en la celebración, resultaría irrelevante un eventual acuerdo de simulación, de guisa que prevalecería la voluntad declarada con las solemnidades legales. ${ }^{56}$

La "Ley de Matrimonio Civil" de 2004, al igual que su predecesora, no contiene disposición alguna tocante a la simulación en el matrimonio, pero sí es de notar que el "Proyecto" durante su tramitación tuvo un artículo (art. 9) que se destinaba expresamente a fijar la disciplina de la simulación en el matrimonio, fundado e inspirado en el canon 1100 del Codex Iuris Canonici, en el cual se distinguían los dos campos operativos de la simulación: a) "simulación total": en cuyo caso se declaraba que "no hay matrimonio"; b) "simulación parcial": en cuyo caso el matrimonio era nulo. ${ }^{57}$ En la Comisión de Constitución del Senado fueron rechazadas diversas indicaciones dirigidas a suprimir este artículo, ${ }^{58}$ pero ellas fueron renovadas y en la votación en sala, finalmente, fue eliminado. ${ }^{59}$

Los argumentos esgrimidos para suprimirlo en el Senado permiten extraer una serie de conclusiones, no sólo en cuanto a lo que entendían los senadores en sede de simulación matrimonial, sino también en cuanto al régimen que de ella pretendieron consagrar sin necesidad de un artículo específico, pero debe advertirse que sólo opinaron los senadores Viera-Gallo, Fernández y Espina, todos por su supresión:

$1^{\circ}$. Si no hay consentimiento, no hay matrimonio, por lo tanto, era inútil reiterar dicha regla: tal fue la opinión compartida por los senadores Viera-Gallo, Espina y Fernández. ${ }^{60}$

$2^{\circ}$. Si se simula un matrimonio, no hay matrimonio, por lo que resultaba innecesaria una regla expresa: esta fue la opinión de los mismos senadores. ${ }^{61}$

Canónico, 54-142, Salamanca, enero junio, 1997, pp. 95-134; Briones Martínez, I. Mª - Domingo Gutiérrez, Ma, "Simulación parcial por exclusión de la prole", en Revista Española de Derecho Canónico 56-147, Salamanca, julio-diciembre, 1999, pp. 721-743.

56 Díez-Picazo, L. - Gullón, A., Sistema de Derecho Civil. IV. Derecho de Familia. Derecho de Sucesiones ${ }^{8}$, Madrid, 2002, p. 80.

${ }^{57}$ El citado artículo 9 disponía lo siguiente en su inciso primero: "No hay matrimonio si no existe consentimiento por parte de ambos contrayentes sobre los elementos esenciales del contrato matrimonial"; y en su inciso segundo: "Si se simula un matrimonio que no corresponde a la real intención de los contrayentes, se contrae inválidamente. También es nulo el matrimonio si uno o ambos cónyuges excluyen, por un acto de voluntad que sea positivo, directo y verificable en el fuero externo, alguno de sus elementos esenciales".

58 "Segundo Informe...", (n. 3), p. 15.

${ }^{59}$ Diario de Sesiones... (n. 36), Sesión 24a, Valparaíso, 7-I-2004, pp. 528-531.

${ }^{60}$ El senador Viera-Gallo hizo presente que: "El inciso primero establece que "No hay matrimonio si no existe consentimiento por parte de ambos contrayentes sobre los elementos esenciales del contrato matrimonial.” ¡Eso es obvio! Porque si no hay consentimiento en tal sentido, no es necesario decirlo. Por lo tanto, la norma estaría de más" (p. 529). De su lado, el senador Espina manifestó que: "Voto a favor de la indicación, porque diversas normas del proyecto -que tiene una finalidad específica- no requieren ser incorporadas en su contexto, como ya lo explicó el Senador señor Viera-Gallo. Evidentemente, el inciso primero establece algo esencial: si no hay consentimiento, no hay matrimonio. No es necesario decirlo, pues ya figura en el Código Civil en forma clara. De manera que repetir aquí una norma ya vigente -además, con una redacción poco feliz-, nada aporta a la aclaración del punto en controversia” (p. 530).

${ }^{61}$ Ídem, p. 529, el senador Viera-Gallo hizo presente que: "Por otro lado, en cuanto a la segunda causal, el inciso segundo señala que "Si se simula un matrimonio que no corresponde a la real intención de los contrayentes, se contrae inválidamente.”. ¡Obvio! De nuevo lo mismo”. 
$3^{\circ}$. Sólo se tuvo en cuenta la simulación del matrimonio cuando ambos contrayentes estaban concertados para simularlo: claramente influidos los senadores por la disciplina de la simulación en sede patrimonial, no fueron capaces de advertir que en el matrimonio la simulación puede traer su origen en la voluntad simulada de sólo uno de los contrayentes. $^{62}$

$4^{\circ}$. Se argumentó, sobre la base de la simulación en los contratos patrimoniales, ; que los terceros perjudicados por el matrimonio podrían instar por la declaración de simulación, fundados en las reglas del derecho común!: tal fue la expresa argumentación del senador Espina, es decir, procedería en tal caso, por ejemplo, la acción pauliana (¡!). ${ }^{63}$

Así, pues, la aplicación de los principios generales contenidos en la ley 19.947, sobre todo en lo tocante al ius conubii, y los generales del derecho común, en el matrimonio ciertos casos de simulación se sitúan en sede de inexistencia del matrimonio, mientras que otros pareciera que pueden encontrar su disciplina en sede de nulidad matrimonial.

\section{$1^{\circ}$. Inexistencia por simulación total y concertada del varón y la mujer: si varón y mujer están} de acuerdo en que su real voluntad no es ejercitar el ius conubii (art. 2 inc. $1^{\circ}$ LMC), aunque de hecho se cumpla con los actos de la celebración del matrimonio, debe sostenerse que no hubo consentimiento matrimonial y, por ende, no hay matrimonio. ${ }^{64}$

La conclusión anterior, por lo demás, es coherente en cuanto a que resulta claro que la simulación del consentimiento excluye, realmente, que exista el necesario consenti-

${ }^{62}$ Ídem, pp. 529-530, en la argumentación del senador Viera-Gallo se apreciaba la precomprensión de una simulación "bilateral”, así expresaba: “¿Cuándo se considera que sería fingido dicho vínculo? Cabe señalar que esta disposición ha sido pensada en forma especial para los inmigrantes que se casan y se quedan en determinado lugar a fin de conseguir visa de residencia permanente, o para salir del territorio cuando no lo pueden abandonar legalmente. Sin embargo, en un país como Chile, ¿de qué manera se prueba que un matrimonio fue simulado, o sea, que no correspondía a la intención de los contrayentes? ¿Qué pasa si se presentan los dos cónyuges y manifiestan que nunca pensaron en casarse, que ello fue una faramalla por la familia y que, por tanto, su matrimonio es nulo, para lo cual presentan dos o tres testigos? ¡Repito: eso sí que se presta para fraude! En lo referente a la tercera causal, la norma del mismo inciso segundo señala que "También es nulo el matrimonio si uno o ambos cónyuges excluyen, por un acto de voluntad que sea positivo, directo y verificable en el fuero externo, alguno de sus elementos esenciales.”. Conforme a esta disposición, podría ocurrir, por ejemplo, que ellos al momento de casarse dejen -como resguardo, por si les va mal- una escritura ante notario manifestando su intención de no procrear y que después presenten ese documento para decir que el matrimonio está nulo porque nunca desearon procrear. Señor Presidente, me parece que es posible aprovecharse de esta norma - no estoy diciendo que quienes la introdujeron o la votaron favorablemente hayan tenido esa intención- en un sentido plenamente fraudulento. En consecuencia, estimo que las dos primeras causales están de sobra y que la tercera se presta para cometer un verdadero fraude, por lo cual apoyo la indicación que hemos firmado varios Senadores tendiente a suprimir el artículo 9".

${ }^{63}$ Ídem, pp. 530-531, sostuvo el senador Espina que: "Por otra parte, lo relativo a los contratos simulados se regula por ley. Por lo tanto, la víctima de una convención de tal naturaleza siempre podrá recurrir ante los tribunales para probarlo. ¿Quién tendría que ejercer la acción? El tercero que se sienta afectado por el mencionado contrato; pero puede impetrar las normas generales de la simulación, pues, obviamente, esto produce efectos patrimoniales. En consecuencia, no es necesario el artículo. Si se aprueba, podría prestarse para eventuales fraudes a la ley".

${ }^{64}$ En este sentido Corral Talciani, H., (n. 15), p. 52; Corral Talciani, H., (n. 13), p. 42. 
miento en el matrimonio y, por ende, éste sería inexistente, entre otras razones, porque la misma "Ley de Matrimonio Civil" tiene como finalidad establecer los requisitos dirigidos a "asegurar el libre y pleno consentimiento de los contrayentes" (art. 2 inc. 1 LMC) y uno de tales requisitos es, precisamente, que éstos "hayan consentido" (art. 4 LMC), lo que presupone el ejercicio efectivo del ius conubii en su dimensión positiva (art. 2 inc. 1 LMC). Pero, además, la "Ley de Matrimonio Civil" se ha preocupado, expresamente, de promover no sólo la "libertad" del consentimiento matrimonial, sino también su "seriedad", y tal es la razón por la cual ha dispuesto la existencia de "cursos de preparación para el matrimonio" (art. 10 inc. 3 LMC), cuyo propósito está paladinamente declarado en el inciso $1^{\circ}$ de su artículo 11: "Los cursos de preparación para el matrimonio, a que se refiere el artículo anterior, tendrán como objetivo promover la libertad y seriedad del consentimiento matrimonial que se debe brindar...”.

Los peligros que se temieron por los legisladores en cuanto a que una regla tal abriría la puerta a todo género de fraudes se diluyen, si se considera la dificultad que tendrían ambos o alguno de los supuestos cónyuges para probar que, realmente, no ejercitó el ius conubii, pues cualquier acto de uno u otro o de ambos posterior a la pretendida celebración que tuviera contenido matrimonial constituiría presunción de haber ejercitado el ius conubii, como, por ejemplo, la vida en común, la procreación, el auxilio que se hubieran prestado, el trato que se hubieran dado y la fama por la que hubieran sido conocidos, etc.

Si, además, la simulación total se hubiera ejecutado con la directa y exclusiva finalidad de defraudar alguna ley, recuérdese que cualquier persona podría impetrar la declaración de inexistencia del matrimonio, en cuyo caso la prueba de haberse pretendido burlar la ley constituiría presunción de la simulación, como al fingir el matrimonio con un extranjero para que no fuera deportado.

$2^{\circ}$. Nulidad por simulación total unilateral: si sólo uno de los supuestos cónyuges hubiera fingido el ejercicio del ius conubii y engañado al otro simulando la celebración de un matrimonio, quien prestó su voluntad real dirigida al matrimonio lo hizo, sin duda alguna, sobre la base de un falso concepto de la realidad, es decir, su voluntad aparece viciada por un error. Tal error recae en una "cualidad personal" del otro contrayente, que consiste en la cualidad de su "seriedad", pues en función de creerlo una persona cabal se movió a otorgar el consentimiento, y tal cualidad, objetivamente, dice relación con la naturaleza o con los fines del matrimonio, al tenor del número $2^{\circ}$ del artículo 8 de la ley 19.947.

En este caso, el temor de utilizar la simulación como instrumento para lograr la nulidad de un matrimonio se atenúa por la restricción a la titularidad de la acción de nulidad basada en el error, supuesto que ella sólo compete al cónyuge que padeció el error (art. 46 inc. $1^{\circ}$, letra b, LMC), sin perjuicio de la prescripción de la acción en tres años (art. 48 letra b, LMC), y de las dificultades de prueba y del papel central que el juez ha de dar a las presunciones que pudieren presentarse.

Por lo demás, otra limitación directa a la torcida aplicación de esta regla la constituye la disciplina penal que se da a la simulación unilateral del matrimonio civil. 
En efecto, junto a la ley 19.947 se aprobó un nuevo artículo 383 del Código Penal, que tipificó el delito de simulación de celebración del matrimonio: "El que engañare a una persona simulando la celebración de matrimonio con ella, sufrirá la pena de reclusión menor en sus grados medio a máximo". La tipificación de este delito sobre la base de los verbos rectores "engañar" y "simular" está en directa relación con la "celebración del matrimonio", por lo tanto sus posibilidades de perpetración son diversas, y una de ellas podría consistir en la simulación del "consentimiento", supuesto que de este requisito del matrimonio se trata, precisamente, en la "Ley de Matrimonio Civil" en su capítulo II: "De la celebración del matrimonio".

$3^{\circ}$. Inocuidad civil de la simulación parcial en sede de inexistencia: aunque es cuestión dudosa, y apartándonos de la doctrina canónica, parece razonable sostener que el ejercicio del ius conubii con exclusión de algún elemento de la naturaleza del matrimonio, en principio, no lo haría inexistente, porque tal exclusión, concertada o unilateral, significaría una especie de ejercicio de la autonomía de la voluntad que no está permitida por el derecho matrimonial en virtud de la regla general del artículo 12 del Código Civil.

Ha de advertirse que en opinión de Corral Talciani una tal simulación también acarrearía la eventual inexistencia del matrimonio, porque el Código Civil exige que el consentimiento matrimonial sea "actual", es decir, no sujeto a modalidades, ${ }^{65}$ aunque ello podría verse desde dos perspectivas diversas, a saber:

a) Irrenunciabilidad de ciertos derechos: en efecto, más que situaciones de "condicionalidad" del consentimiento matrimonial, la exclusión de algún elemento de la naturaleza del matrimonio constituiría un supuesto de "renuncia" a un derecho indisponible, pues, en muchos casos tal exclusión implicaría una "renuncia" a un derecho que no está establecido en el solo interés del renunciante, sino que también a favor del otro cónyuge o en interés de la sociedad, por ejemplo: la renuncia a los derechos emanados del matrimonio, por la naturaleza recíproca de ellos, como el derecho a que le sea guardada fe, el derecho a la vida en común, el derecho al socorro, al respeto y protección, o al débito conyugal, que importaría excluir la procreación, etc. y, por ende, una tal renuncia sería ineficaz.

b) Incapacidad matrimonial: en el caso de un consentimiento matrimonial condicionado se abre la puerta a la incapacidad del número $4^{\circ}$ del artículo 5 de la ley 19.947, es decir, la inclusión de una cierta condición constituiría un caso concreto de carencia de suficiente discernimiento para comprender y comprometerse con los derechos y deberes esenciales del matrimonio y, por ende, se alzaría en capítulo de nulidad matrimonial y no de inexistencia. ${ }^{66}$

\footnotetext{
${ }^{65}$ Corral Talciani, H., (n., 13), pp. 42-43.

${ }^{66}$ Vid. Barrientos Grandón, J. y Novales Alquézar, A. (n. 1), p. 119.
} 


\subsection{Presencia del Oficial del Registro Civil}

Bajo la vigencia de la "Ley de Matrimonio Civil” de 1884 apareció como indudable para la doctrina y la jurisprudencia chilenas que la presencia del Oficial de Registro Civil era una condición o requisito de existencia del matrimonio y fue, precisamente, a propósito de ciertos "matrimonios" celebrados ante funcionarios diversos al del Registro Civil que la Corte Suprema sentó la opinión conforme a la cual en tales casos no existía matrimonio. ${ }^{67}$

En el contexto de la nueva "Ley de Matrimonio Civil" la situación anterior sólo adviene equiparable a aquellos matrimonios que son celebrados bajo la forma mere civile, es decir, íntegramente ante el Oficial del Registro Civil, pues el inciso primero de su artículo 17 prescribe perentoriamente que: "El matrimonio se celebrará ante el Oficial del Registro Civil", que debe ser el mismo que intervino en la realización de las diligencias de la manifestación e información (arts. 9 a 16 LMC). ${ }^{68}$

Por lo que se lleva dicho, se mantiene como requisito de existencia del matrimonio celebrado bajo forma meramente civil que éste se lleve a cabo en presencia de un Oficial del Registro Civil.

Se pregunta ahora: ¿La ausencia de ministro de culto debidamente facultado en la celebración del matrimonio bajo forma religiosa vuelve inexistente el matrimonio? López Díaz y Corral Talciani se inclinan por la afirmativa, ${ }^{69}$ pero no parece ser esta opinión indiscutible, pues, es necesario distinguir dos situaciones diversas:

a) Matrimonio bajo forma religiosa no inscrito: al tenor del artículo 20 de la ley 19.947, el matrimonio celebrado ante un ministro de culto debidamente facultado no produce efectos civiles, pues éstos sólo se generan a partir de la "inscripción" del matrimonio, de guisa que si no se inscribe en el plazo y formas legales, es irrelevante para la ley civil el que se haya o no celebrado ante ministro de culto facultado, pues tal matrimonio no existe para la ley civil.

${ }^{67}$ La Corte Suprema, por vía de casación, en sentencia del 6 de octubre de 1953 declaraba inexistente un "matrimonio" actuado ante un cónsul chileno en el extranjero: "Debe concluirse, pues, que el matrimonio cuya inexistencia sostiene la demandada no se ha celebrado en la forma dispuesta por la ley; ésta prescribe en el artículo 16 de la Ley de 10 de enero de 1884 que el matrimonio se celebrará ante el Oficial del Registro Civil, y el artículo 18 agrega que inmediatamente después de celebrarse, el oficial levantará acta de todo lo obrado y procederá a hacer la inscripción en los libros del Registro Civil en la forma prescrita por el reglamento respectivo. En la especie no intervino el Oficial Civil y, por ende, no hubo inscripción en su registro, omitiéndose con ello requisitos esenciales para la existencia del acto, según lo dispuesto en el artículo $1^{\circ}$ del mismo texto, en cuya virtud el matrimonio que no se celebre con arreglo a las disposiciones de esa ley no produce efectos civiles. El acto que no se celebra ante el funcionario público llamado a intervenir en él, para la ley no existe, como no existiría si los contrayentes no manifestaran ante él su voluntad de contraer matrimonio o no hubiera entre ellos diferencia de sexo" (Corte Suprema, Cas. civ. 26-IX-1953, cons. 13 en Revista de Derecho y Jurisprudencia, L, Santiago de Chile, 1954, II ${ }^{\mathrm{a}}$ Parte, Sec. I ${ }^{\mathrm{a}}$, p. 392).

${ }^{68}$ En el mismo sentido Corral Talciani, H., (n. 15), p. 52.

${ }^{69}$ López Díaz, C. (n. 1), p. 153; Corral Talciani, H. (n. 13), p. 43. 
b) Matrimonio bajo forma religiosa inscrito: la ley 19.947 no contiene exigencia alguna respecto de la persona del ministro de culto ante quien ha de celebrarse el matrimonio religioso, pues sólo le interesa que se celebre "ante entidades religiosas de derecho público" y es de un tal matrimonio así celebrado del que se genera el derecho a obtener que produzca "los mismos efectos que el matrimonio civil", siempre que cumpla "con los requisitos contemplados en la ley" (art. 20 inc. $1^{\circ}$ ) y, por lo mismo, la ley nada exige respecto del ministro culto al tratar del acta que debe otorgar la entidad religiosa en la que se acredite la celebración (art. 20 inc. $2^{\circ}$ ) y la Ley de Registro Civil se limita a incluir como exigencia de la referida acta la indicación del "nombre y los apellidos del ministro de culto, así como su número de cédula de identidad” (art. 40 bis $n^{\circ}$ 9). Así, pues, la exigencia es de celebración "ante una entidad religiosa de derecho público" y no ante "un ministro de culto", porque la determinación del ministro de culto habilitado para la celebración de un matrimonio religioso no es competencia del derecho del Estado, sino que cae en el ámbito de la libertad religiosa reconocida a las entidades religiosas (art. 7, letra b, ley 19.638).

Celebrado un matrimonio ante una entidad religiosa y extendida el acta correspondiente, para que produzca los mismos efectos que el matrimonio civil, debe "inscribirse" (el matrimonio) en el Registro Civil, y es aquí donde la ley impone al Oficial del Registro Civil el deber funcionario de verificar "el cumplimiento de los requisitos legales" (art. 20 inc. $3^{\circ}$ ), de guisa que si el matrimonio no se hubiera celebrado ante una "entidad religiosa" debe denegar la inscripción, pero no puede denegarla en función de hacer juicio sobre la presencia o no de un ministro de culto y de su competencia religiosa o no para actuar en ejercicio de su función eclesiástica, en la celebración religiosa, pues, no está facultado para ello.

Cuestión diversa de la anterior es la relativa a la "inscripción del matrimonio" y a sus requisitos, uno de los cuales es el que contenga "El documento que acredite la personería del respectivo ministro de culto" (art. 40 ter LRC), declarado como "requisito esencial" de una inscripción de un matrimonio religioso, pues su falta afectaría a la "inscripción". Aquí Corral Talciani asiente a la opinión que, ya habíamos expresado, ${ }^{70}$ conforme a la cual "la posible declaración de nulidad de la inscripción (por falta de mención de los requisitos esenciales) no determinará la inexistencia del matrimonio religioso, si bien influirá en la prueba de su reconocimiento civil". ${ }^{71}$

\subsection{De la inscripción del matrimonio religioso}

El artículo 20 de la "Ley de Matrimonio Civil" ha dispuesto que los matrimonios celebrados ante entidades religiosas de derecho público carecen de todo reconocimiento

\footnotetext{
${ }^{70}$ Vid. Barrientos Grandón, J. y Novales Alquézar, A. (n. 1), p. 191.

${ }^{71}$ Corral Talciani, H., (n. 13), n. 14, p. 43; y antes en Corral Talciani, H., (n. 15), p. 52, n. 50.
} 
civil si no se procede a la inscripción ante un Oficial de Registro Civil, pues, como lo prescribe la parte final de su inciso segundo: "si no se inscribiere en el plazo fijado, tal matrimonio no producirá efecto civil alguno".

La singular disciplina del régimen de registro del matrimonio en el sistema chileno da origen a supuestos en los cuales la ley 19.947 desconoce todo efecto civil a los matrimonios religiosos y, de esta manera, indirectamente ha introducido un requisito de existencia para el matrimonio civil, cuando su celebración se ha iniciado ante un ministro de una entidad religiosa de derecho público, a saber: a) la inscripción del matrimonio.

a) Inscripción del matrimonio: en el peculiar régimen de registro chileno lo que se inscribe es el matrimonio y no el acta matrimonial y, de acuerdo con el citado artículo 20 de la ley: "Si no se inscribiere en el plazo fijado, tal matrimonio no producirá efecto civil alguno”. Así, pues, la inscripción del matrimonio se ha configurado como un requisito de existencia del matrimonio civil, de modo que si faltare tal inscripción, no existe matrimonio civil. ${ }^{72}$

b) ¿Se requiere la validez de la inscripción?: se ha anticipado que el artículo 40 ter de la ley de Registro Civil en su inciso final declara que algunas de las menciones que deben consignarse en la inscripción del matrimonio constituyen "requisitos esenciales" de ella, de manera que su falta conduce a que tal inscripción no produzca efecto alguno. Tales requisitos esenciales son: a) el acta otorgada por la entidad religiosa; b) "el documento que acredite la personería del respectivo ministro de culto"; c) "el hecho de haberse otorgado por los requirentes de la inscripción, ante el Oficial del Registro Civil, la ratificación del consentimiento prestado ante el ministro de culto, y en conformidad a lo dispuesto en el artículo 20 de la Ley de Matrimonio Civil"; y d) "la firma de los requirentes de la inscripción y del Oficial del Registro Civil”.

Surge entonces la cuestión de determinar en qué situación jurídica queda el matrimonio celebrado ante la entidad religiosa si la inscripción de ella careciere de los requisitos que la ley ha declarado como esenciales, punto éste que acarrea más de alguna dificultad:

a) En principio podría sostenerse que si la inscripción es, en estos casos, requisito de existencia del matrimonio civil y no una formalidad establecida por vía de prueba, caída la inscripción caería también el matrimonio civil y, por ende, dejaría de producir efectos civiles, de modo que habría que tenerlo como inexistente ante la ley civil.

b) Una tan rigurosa interpretación de la regla del artículo 20 pareciera que no se conciliaría con los términos de ella misma, pues lo que exige el inciso $1^{\circ}$ del artículo 20, en relación con su inciso final y el artículo 40 ter de la LrC., es sim-

${ }^{72}$ En el mismo sentido Corral Talciani, H., (n. 15), p. 52; y Domínguez Hidalgo, C., "Reformas a la formación y efectos del matrimonio en la nueva ley: un apunte general”, en Colegio de Abogados (n. 15), p. 11. 
plemente la "inscripción ante un Oficial del Registro Civil", de modo que con tal inscripción el matrimonio civil se tendría por existente, de guisa que lo que ocurriría si luego cae dicha inscripción es que no podría acudirse a ella como prueba del matrimonio, si bien esta interpretación podría pugnar con los efectos de una declaración judicial de nulidad de la inscripción. ${ }^{73}$

\section{Conclusión}

La nueva "Ley de Matrimonio Civil" ha reanimado nuestro, escasamente, desarrollado derecho matrimonial y en sede de requisitos de existencia del matrimonio ha venido a confirmarlos, junto a su consecuencia: inexistencia, por la "dimensión negativa" del ius conubii, lo que exige una relectura de los tres requisitos tradicionalmente estudiados por la doctrina junto a uno nuevo, relectura que ya ha comenzado a generar cuestiones dogmáticas de interés, entre otras, en sede de ausencia de consentimiento por fuerza física, por error y por simulación, y en sede de matrimonios religiosos a los que se pretenda dar los mismos efectos que a un matrimonio civil.

\section{BIBLIOGRAFÍA}

Alessandri Besa, A., La nulidad y la rescisión en el derecho civil chileno, ${ }^{2}$ Editorial Jurídica de Chile, Santiago de Chile, s/f.

Alessandri Rodríguez, A., - Somarriva Undurraga, M., Curso de Derecho Civil... redactado y puesto al día por Antonio Vodanovic H., IV. Fuentes de las obligaciones, Santiago de Chile, 1942.

Barrientos Grandón, J., "Ley 19.947 sobre matrimonio civil publicada en el Diario Oficial de 17 de mayo de 2004", en Revista Chilena de Derecho Privado. Fernando Fueyo Laneri, 2, Santiago de Chile, 2004, pp. 233-241.

- "De la "tradición" y su definición en el Código Civil chileno. A propósito del artículo 670", en Revista Chilena de Derecho Privado Fernando Fueyo Laneri, 1, Santiago de Chile, diciembre, 2003, pp. 11-108.

- $\quad$ "Fuentes del título 'De los actos y declaraciones de voluntad' del Código Civil”, en Cuadernos de Análisis Jurídico, 28, Estudios de Derecho Civil, Universidad Diego Portales, Santiago de Chile, julio 1983, pp. 68-70.

Barrientos Grandón, J. y Novales Alquézar, A., Nuevo derecho matrimonial chileno, Lexis Nexis, Santiago de Chile, 2004.

Barros Errázuriz, A., Curso de Derecho Civil. Segundo Año. Según el programa aprobado por la Facultad de Derecho de la Universidad del Estado, ${ }^{3}$ Imprenta Cervantes, Santiago de Chile, 1921.

${ }^{73}$ Comparte esta opinión Corral Talciani, H., (n. 15), p. 52, n. 50; Corral Talciani, H., (n. 13), n 14, p. 43. 
Briones Martínez, I. Ma - Domingo Gutiérrez, Ma "Simulación parcial por exclusión de la prole”, en Revista Española de Derecho Canónico 56-147, Salamanca, julio-diciembre, 1999, pp. 721-743.

Carrodeguas Nieto, C., "La exclusión de la educación de la prole", en Revista Española de Derecho Canónico, 54-142, Salamanca, enero junio, 1997, pp. 95-134.

Castro Larraín, O., "Matrimonio putativo", en Revista de Derecho y Jurisprudencia, XXXVII, Santiago de Chile, 1940.

Claro Solar, L., Explicaciones de Derecho Civil chileno y comparado, I, Santiago de Chile, 1932.

Corral Talciani, $\mathrm{H}$., "El régimen de los requisitos del matrimonio y de la nulidad en la nueva ley de matrimonio civil”, en Cuadernos de Extensión Jurídica, 11, Matrimonio civil y divorcio. Análisis crítico y criterios para la aplicación de la Ley $N^{\circ} 19.947$, de 2004, Universidad de Los Andes, Santiago de Chile, 2005, pp. 37-75.

- $\quad$ "El régimen de Nulidad Matrimonial en la Nueva Ley de Matrimonio civil”, en Colegio de Abogados de Chile, Seminario: Nueva Ley de Matrimonio Civil, Ley $N^{\circ} 19.947$, Santiago de Chile, 2004. pp. 27-56.

Court Murasso, E., Nueva Ley de Matrimonio Civil. Ley 19.947, Universidad Adolfo IbáñezLegis, Bogotá, 2004.

De la Maza Gazmuri, I., "El error en las cualidades personales del otro contrayente en la Ley 19.947", en Ius et Praxis. Derecho en la Región, Año 11, No 1, Talca, 2005, pp. 11-35.

De la Maza Rivadeneira, L., Derecho Civil. Contratos, Universitaria, Santiago de Chile, 1954.

Díez-Picazo, L. - Gullón, A., Sistema de Derecho Civil. IV. Derecho de Familia. Derecho de Sucesiones, ${ }^{8}$ Madrid, 2002.

Domínguez Hidalgo, C., "Reformas a la formación y efectos del matrimonio en la nueva ley: un apunte general", en Colegio de Abogados de Chile, Seminario: Nueva Ley de Matrimonio Civil, Ley $N^{\circ}$ 19.947, Santiago de Chile, 2004. pp. 3-24.

Ducci Claro, C., Derecho civil, Editorial Jurídica de Chile, Santiago de Chile, 1988.

Fueyo Laneri, F. Derecho Civil, VI, Derecho de Familia, I, Santiago de Chile, 1959.

García Cantero, G., "Chile estrena divorcio (Ley 17 de mayo 2004", en Actualidad Civil, 5, Madrid, 2005, pp. 517-533.

- “¿Derecho a no casarse?”, en Actualidad Civil, 1, Madrid, 2004, pp. 13-22.

Larraín Ríos, H., Lecciones de Derecho Civil, Editorial Jurídica de Chile, Santiago de Chile, 1994.

León Hurtado, A., La voluntad y la capacidad en los actos jurídicos, ${ }^{3}$ Editorial Jurídica de Chile, Santiago de Chile, 1990.

López Díaz, C. Manual de Derecho de Familia y Tribunales de Familia, Librotecnia, Santiago de Chile, 2005.

López Santa María, J., Los contratos. Parte general, ${ }^{3}$ Editorial Jurídica de Chile, Santiago de Chile, 2001.

Meza Barros, R., Manual de Derecho de Familia, ${ }^{2}$ Editorial Jurídica de Chile, Santiago de Chile, 1989.

Paul Errázuriz, H., Estudio crítico de la jurisprudencia recaída sobre los artículos $1^{\circ}$ a $8^{\circ}$ de la Ley de Matrimonio Civil, Memoria de Prueba para optar al Grado de Licenciado en Ciencias Jurídicas y Sociales de la Universidad de Chile, Santiago de Chile, 1957.

Pescio Vargas, V., Manual de Derecho Civil, II, Editorial Jurídica, Santiago de Chile, 1978.

Ramos Pazos, R., Derecho de familia, ${ }^{5}$ Editorial Jurídica de Chile, Santiago de Chile, 2005.

- Derecho de familia, ${ }^{4}$ Editorial Jurídica de Chile, Santiago de Chile, 2003.

Rossel SaAvedra, E., Manual de Derecho de Familia ${ }^{7}$, Editorial Jurídica de Chile, Santiago de Chile, 1993. 
Somarriva Undurraga, M., Derecho de Familia, Editorial Jurídica de Chile, Santiago de Chile, 1983.

Velasco Letelier, E., De la disolución del matrimonio, Editiorial Jurídica de Chile, Santiago de Chile, 1973.

VIal Del Río, V., Teoría general del acto jurídico ${ }^{5}$, Editorial Jurídica de Chile, Santiago de Chile, 2003.

Zachariae, K. S., Le droit civil français (Traducción de la $5^{\text {a }}$ ed. en alemán), Paris, Auguste Durand, 1854 , t. 1.

Diario de Sesiones del Senado. Nueva Ley de Matrimonio Civil, Sesión 24a , Valparaíso, miércoles 7-I-2004.

"Segundo Informe de la Comisión de Constitución, Legislación, Justicia y Reglamento, recaído en el proyecto de ley, en segundo trámite constitucional, que establece una nueva ley de matrimonio civil”, Valparaíso, 15 de diciembre de 2003, Boletín 1.759-18. 